Article

\title{
Diversity, Equity, and Inclusion and the Salience of Publicly Disclosing Demographic Data in American Environmental Nonprofits
}

\author{
Dorceta E. Taylor*, Sophia Paul and Ember McCoy \\ School for Environment and Sustainability, University of Michigan, Ann Arbor, MI 48109-1115, USA; \\ sophiakp@umich.edu (S.P.); embermcc@umich.edu (E.M.) \\ * Correspondence: dorceta@umich.edu
}

Received: 9 August 2019; Accepted: 23 September 2019; Published: 3 October 2019

\begin{abstract}
There has been a scholarly interest in the demographic characteristics of American environmental organizations since the 1960s, but until recently there was no readily available way of knowing the composition of the staff or board of these institutions as few revealed any of their demographic data publicly. For the past five years, there has been a high-profile campaign to get environmental nonprofits to disclose their demographic data. This paper examines 12,054 small, medium-sized, and large environmental organizations to find out how many of them have released diversity data on GuideStar. The article also examines how the state in which organizations are located, region of the country, urban or rural setting, organizational typology, amount of revenue, size of the staff, size of the board, gender of the chief executive officer (CEO), race of the CEO, and the year of completion of the GuideStar profile influenced the disclosure of diversity data. The researchers collected financial data from Internal Revenue Service tax forms and diversity data from GuideStar. The study found that $3.7 \%$ of the nonprofits studied divulged diversity data. However, organizations in the Pacific and Mid-Atlantic regions were most likely and nonprofits in the South least likely to report diversity data. Urban nonprofits were more likely to divulge diversity data than those located in the suburbs or in the rural areas. The highest level of reporting was in Washington, D.C. In addition, environmental justice organizations were more likely to disclose diversity data than other types of organizations. The larger the staff and the higher the revenue, the more likely it is that the organization divulged its diversity data. Organizations with female CEOs were more likely to reveal diversity data than male-headed nonprofits. Environmental organizations with ethnic/racial minority CEOs were also more likely to disclose demographic data than organizations with white CEOs.
\end{abstract}

Keywords: social sustainability; social responsibility; transparency; gender; race; ethnicity

\section{Introduction}

Though U.S. environmental organizations have been in existence for nearly two centuries, it is still difficult to assess their level of racial diversity or find information on other demographic characteristics of these institutions. Despite the growing interest in the racial/ethnic and gender characteristics of environmental nonprofit staff, membership, and boards, few of the institutions publicly disclose these types of data. Hence, this paper seeks to examine an understudied aspect of the behavior of American environmental nonprofits-the disclosure of diversity information. The paper assesses the extent to which environmental institutions reveal data on the demographic characteristics of their staff and board. It will explore two main questions: Which organizations are most prone to reveal diversity data? What accounts for the variations in the levels of public reporting? 


\subsection{Historical Context}

For most of the nineteenth century, the founders and members of environmental organizations were wealthy, white, and male. Though the organizations formulated policies that affected the public, at times, the leadership and membership of these entities went to great lengths to exclude rather than include the masses. This practice continued throughout the nineteenth century, even after wealthy white females became founders, members, and financial backers of the Appalachian Mountain Club, Sierra Club, National Audubon Society, and Save the Redwoods League [1-6].

The environmental organizations founded by white elites closed their doors to the white working-class well into the twentieth century. However, white working-class hunters and anglers founded a few organizations such as the Game Protective Association in 1902 in Wyoming and the Adirondack Game and Fish Protective Association in 1903 in New York [1,7]. Additionally, the Izaak Walton League, founded in Chicago in 1922, attracted a large following by appealing to the middleand working-class outdoor recreationists [1,8,9].

The tentative forays into engaging the white working-class notwithstanding, by and large, environmental organizations served whites and snubbed people of color. Though the historical record shows that people of color made essential contributions to environmental protection, environmentalists did not incorporate ethnic minorities into the environmental movement or institutions for a long time. For instance, scholars have documented the role people of color played in the construction and stewardship of national parks and forests and the experiences of ethnic minorities in these spaces [1,10-12]. Yet, people of color were excluded from the membership and workforce of most environmental organizations throughout the nineteenth century and for much of the twentieth century.

The lack of racial and ethnic diversity in environmental organizations went mostly unnoticed until the 1960s when academics and activists called attention to the overwhelming whiteness of the environmental movement and its workforce. Environmental leaders responded to the criticism by arguing that increasing the racial diversity of their staff or membership was not a part of their environmental mission. The question of racial diversity proved divisive within some organizations. For instance, though David Brower declared that the Sierra Club's membership was open to people of "the four recognized colors" in 1959, the debate over whether the club should admit people of color into its membership dragged on for some time. During one discussion, attorney and former director of the club, Bestor Robinson, said: "Now wait a minute, this is not an integration club; this is a conservation club." Robinson openly expressed a sentiment that many in the club shared. That is, racial inclusion was a social justice or civil rights issue, and these topics were not related to conservation. Since club members did not see a connection between social justice and the environment, they did not believe that increasing racial diversity in the organization was a project the institution should undertake. The resolution proposing that the club admit people of color failed to pass [8].

Efforts to enhance the racial diversity of environmental organizations got a boost in 1990. That year, as preparations for the celebration of Earth Day 20 entered the final stages, people of color environmental justice activists published a letter in the New York Times claiming that few people of color worked in conservation nonprofits. Activists addressed the letter to the ten largest environmental organizations. The letter suggested that the establishments had discriminatory hiring practices. It also pointed to the benefits that enviros could reap if they worked more collaboratively with communities of color and hired more ethnic and racial minorities [13].

Taken aback, conservation leaders struggled to explain the lack of people of color on their staff and vowed to increase the recruitment of ethnic and racial minorities into their institutions. In their explanations, environmental leaders educed narrative tropes that placed the blame for lack of involvement in environmental organizations squarely on the shoulders of people of color. Environmental leaders claimed that people of color (especially blacks) were not working in environmental organizations because they were not knowledgeable about the environment and lacked awareness about environmental issues. Conservationists also argued that people of color did not apply for jobs in their establishments and would not stay in such workplaces if hired. People of 
color were also said to desire salaries that were too high for the environmental organizations to afford to pay $[13,14]$.

Leading environmentalists also made the distinction between concern for the environment, concern for social justice issues, and social responsibility. For instance, Fred Krupp, executive director of the Environmental Defense Fund, responded to the letter by arguing that minorities are "cause-oriented," and are therefore attracted to issues such as discrimination and poverty rather than to environmental issues. But Krupp admitted that "the truth is that environmental groups have done a miserable job of reaching out to minorities." Bob Norman, the National Audubon's director of human resources, had a slightly different interpretation. He agreed that his organization had a terrible track record when it came to minority engagement, but he did not think that racism was a factor in hiring. Hence, he conceded that "We are not proud of our record-we are terrible." However, he hastened to add, "I can't believe it is racism. We are not getting the candidates from the minority community" $[13,14]$.

In making their arguments, Krupp, Norman, and others who suggested that minorities were not interested in the environment, did not provide any evidence to support their claims. They were also ignoring studies of ethnic minority students and other people of color that show strong interest in working in the environmental workforce [15-17]. By the time environmental justice activists penned the letter to the New York Times and the big green groups, people of color had formed grassroots environmental groups all over the country. The signatories to the letter were representatives of grassroots environmental groups that attracted the support of people of color, nonetheless, environmental leaders ignored that fact and framed people of color as disinterested nonparticipants in environmental affairs. About a year after publishing the letter, hundreds of environmental justice leaders converged on Washington D.C. for the First National People of Color Environmental Leadership Summit. The Principles of Environmental Justice were finalized at this gathering [18].

People of color have demonstrated their interest in environmental issues and governance. Hundreds of environmental organizations, founded and administered by people of color, are currently in operation. Moreover, there continues to be a proliferation of outdoor recreation and wilderness-experience groups spearheaded by people of color [10].

Consequently, studies continue to show that people of color are interested in working in environmental nonprofits [10,17,19-22]. People of color reject the disinterest thesis and argue, instead, that there are structural factors such as poor recruitment, discrimination, cultural isolation, lack of mentoring, and limited promotions that contribute to the low levels of ethnic minorities in the environmental workforce [22].

The stereotypes used to describe people of color and their relationship to environmental organizations in 1990 are still in vogue today. Some environmental leaders gave similar explanations for the lack of racial diversity in their organizations in The State of Diversity in Environmental Institutions, a report released in 2014. Some of the leaders surveyed for the study felt that paying attention to racial diversity is incompatible with their environmental mission and could put the sustainability of their organizations in jeopardy [22].

Why should environmental organizations care about workforce diversity? Environmental organizations need to pay attention to diversity, as it is a key driver of institutional effectiveness. Organizational research bears this out. Studies of corporate executives from around the world argue that diverse backgrounds, perspectives, and experiences in their workforce are crucial to innovation and the development of new ideas. Executives also contend that having a diverse and inclusive workplace is critical to recruiting, attracting, and retaining top talent [23,24]. Corporate executives are not the only ones making these arguments. Scholars contend that workplace diversity is a key factor in building cognitive growth, improving critical thinking, problem solving, and skills acquisition, and enhancing productivity [25-29]. Others suggest that greater heterogeneity in the workplace can lead to more committed, better satisfied, and higher performing employees [30]. 
There is another compelling reason why environmental organizations should be concerned about workplace diversity. The United States is undergoing a demographic shift that will affect the racial composition of the environmental workforce. The census projects that racial/ethnic minorities will constitute a majority of the United States population by 2045 [31,32].

Environmental issues are complex. Environmental organizations deal with local, national, and global issues that are best tackled by people who can solve problems at macro and micro scales. Excluding racial/ethnic minorities from the workforce means ignoring the skills, talents, insights, and experiences that exists in roughly $42 \%$ of the population today [33]. This means that organization that want to be successful and influential, will have to recruit, hire, and retain minorities in their workforce. This is particularly true for organizations that want to hire talented people. Ergo, if environmentalists want to succeed in their mission to protect the environment and foster greater sustainability, they have to engage more people of color in meaningful ways since ethnic minorities currently comprise a rapidly growing segment of the population and will constitute a majority of it in a few decades.

Consequently, some environmental organizations have undertaken diversity initiatives, and the idea of increasing racial diversity has gained credence among environmental activists. This shift occurred because it is increasingly difficult for white environmental activists to claim that people of color (who have founded and joined environmental justice and climate justice organizations by the thousands) do not know or care about the environment.

\subsection{Efforts to Promote the Reporting of Diversity Data}

The paucity of demographic information about environmental nonprofits led to concerted efforts in 2014 to get the organizations to report such data. That year, diversity advocates from Green 2.0-a people-of-color-led, multiracial group of environmental professionals-teamed up with GuideStar, an organization that has a repository of financial and descriptive information for over 2.7 million nonprofits, to create a program to help environmental organizations provide their demographic data as they update their institution's profile. The GuideStar system opened in October, shortly after The State of Diversity in Environmental Institutions was released [34,35]. The report called for greater inclusivity in environmental organizations, increased racial/ethnic diversity, and more sensitivity to and recognition of lesbian, gay, bisexual, transgender, and queer (LGBTQ) issues in the organizations. The document also called for increased public disclosure of demographic data by environmental organizations [22].

This raises the question-why is transparency relevant in the environmental context? This paper is concerned with one aspect of transparency - the public release of demographic data. In this respect, transparency is an important element of diversity. It allows environmental organizations and third parties to identify baselines, set targets, reveal accomplishments, and measure progress on achieving goals. As the following excerpts make clear, leaders of the most powerful environmental organizations recognize that data gathering, tracking, and the release of diversity data as important elements of strengthening the environmental movement.

When the data-collection program debuted, several leaders of major environmental organizations opined about the need to increase racial and ethnic diversity in environmental nonprofits and pledged their support for the effort to increase tracking, disclosure, and transparency. Hence, Tripp Van Noppen, the president of Earthjustice, exclaimed: "Earthjustice continues to support this work, and we are looking forward to working with Green 2.0, GuideStar and other NGOs to gather information and develop real solutions to the under-representation of people of color in our organization and the environmental movement writ large." David Yarnold, the president and chief executive officer of the National Audubon Society, supported more extensive tracking when he declared, "What matters is not our intentions or what we say-what matters is what we do. We need to operate differently, recruit differently and hire differently. Tracking progress is crucial" [34].

The president of the Union of Concerned Scientists (UCS), Ken Kimmell, went a step further by arguing that there is an urgent need for comprehensive tracking. He said, “The Union of Concerned 
Scientists values data and transparency as critical tools for problem solving on any issue, diversity included. UCS has thus welcomed the call by Green 2.0, GuideStar and D5 to share diversity data, since tracking data at scale, is long overdue. We are committed to helping the partnership improve data collection and encourage all environmental organizations to be part of the solution so that the sector can rigorously assess how our efforts are making a difference" [34].

The president and chief executive officer of The Nature Conservancy, Mark Tercek, also called for increased transparency as he argued that it was a critical step in closing what he saw as the diversity gap. He said, "The Nature Conservancy is pleased to support Green 2.0's diversity data initiative. Increasing transparency is a critical step in closing the diversity gap in the environmental movement ..." [34].

Rhea Suh, president of the Natural Resources Defense Council (NRDC) and the only woman of color to head an enviro this large, issued this statement. "Transparency is a key driver of change, and that's exactly what's needed if we are to strengthen the environmental movement. Green 2.0 and Guidestar's work is critical to helping us expand diversity among our staff ... " [34].

Michael Brune, executive director of the Sierra Club, also supported to the effort. He noted that "The Sierra Club is proud to have supported the Green 2.0 report and we look forward to participating in this next phase of collaboration with GuideStar ..." The president/chief executive officer of the Defenders of Wildlife was also supportive of the initiative. He stated that "Defenders of Wildlife is a national, nonprofit membership organization dedicated to the protection of all native wild animals and plants in their natural communities. Our employees work in an environment that is inclusive and honors each of our unique perspectives and backgrounds. We believe that the conservation of biological diversity is best advanced by the contributions of people of diverse backgrounds, experiences, beliefs, and cultures..." [34]. The leaders mentioned above vowed to disclose their organization's demographic data on GuideStar and the people of color activists in Green 2.0 who spearheaded the effort were optimistic that change was afoot [34].

Presidents of influential environmental grantmaking foundations also weighed in on the issue. The presidents of the Bullitt Foundation, Ford Foundation, Hewlett Foundation, Kresge Foundation, the Rockefeller Brothers Fund, and Wilburforce Foundation urged environmental organizations as well as funders to collect and release demographic data [34,36]. In 2015, Rip Rapson, President of the Kresge Foundation, reflected on the progress of the transparency campaign in op-ed in the San Francisco Chronicle. Rapson said, "I wish I could report that [this campaign] has lit a fire under environmental funders[.] [R] eporting is a modest first step in bringing genuine diversity to the mainstream environmental movement. But it is an indispensable one[.] 'Closed clubs' in any segment of our society should be relics of the distant past, and especially so in a movement with such high ideals for creating a better and more healthful world" [37].

Hence, this paper assesses the outcomes of the efforts to increase transparency and reveal demographic data in environmental nonprofits. It will conduct a comprehensive assessment of the state of reporting since the launch of the transparency campaign. It will examine the extent to which organizations are revealing their diversity data, which ones are reporting, and how levels of reporting have changed from 2014 to 2018.

\section{Relevant Research}

\subsection{Institutional Diversity}

\subsubsection{Gender Diversity}

As mentioned above, scholars began studying the demographic characteristics of the environmental movement, environmental organizations, and activists in the 1960s and found them to be influential, but predominantly white and upper and middle-class. Males dominated the leadership [38-41]. The earliest call for greater diversity in environmental organizations and the movement led to substantial improvements in gender diversity. Hence, since the 1980s, studies have shown that the percentage of 
women in the environmental workforce has increased steadily. A 1993 study found that the percentage of female professionals working in natural resources agencies was 19.4\% [42]. However, between 2006 and 2016, numerous studies found that the staff of environmental organizations and agencies ranged from $24 \%$ to $58 \%$ female $[19,22,43,44]$.

Despite these gains, females are underrepresented in the upper echelons of environmental institutions [20,22]. In 1988, a study on the leadership of 265 environmental organizations found that $21 \%$ of the senior leaders were females [45]. In 2014, Taylor [21] collected data on the leadership of 324 environmental organizations and found that $49.7 \%$ of the senior staff of these organizations were female. But, the study also found that only $28.3 \%$ of the organizations had a female president, $35.8 \%$ had females on their boards, and $30.6 \%$ had female board chairs.

\subsubsection{Racial and Ethnic Diversity}

The percentage of racial and ethnic minorities on the staff of environmental nonprofits has increased slowly over time. An informal poll of the ten largest enviros revealed that, in 1990, ethnic minorities comprised only about $2 \%$ of the staff of those organizations [14]. When Stanton [46] studied the racial composition of the staff of 61 conservation organizations in 2002 , he found that $11 \%$ of the 6346 staff were people of color. Three years later, he found that $14 \%$ of the 4037 staff studied were ethnic minorities [47]. Other researchers report similar findings. A 2007 study found that $14.6 \%$ of the staff of 166 environmental organization were of ethnic minorities [19]. Data collected in 2014 found that people of color constituted about $12 \%$ of the staff of the 324 environmental nonprofits studied. Few ethnic minorities occupied top leadership positions in these organizations [21].

In comparison, progress on the racial diversity of the staff of government environmental agencies is more pronounced but still halting. Only $8.4 \%$ of the natural resources that the professionals surveyed in 1993 were of ethnic minorities [42]. In 2006, analysis of the demographic characteristics of the federal land management workforce found that minorities accounted for less than $20 \%$ of the staff at all the agencies studied [44]. However, by 2015, the percentage of minorities on staff at the ten agencies studied increased to over $20 \%[19,43]$.

\subsection{Progress on Racial/Ethnic Diversity, Tracking, and Transparency}

In recent years some of the most prominent environmental organizations have made high-profile hires and appointments of people of color to senior leadership positions. For instance, NRDC and the Sierra Club each hired the first people of color into Presidential roles in recent years. Rhea Suh, a Korean American woman, was hired as the President of NRDC. Allison Chin was the first person of color to serve as President of the Sierra Club's Board of Directors (serving from 2008-2010 and 2012-2013); Aaron Mair, the first African American President of the Sierra Club's Board of Directors, served from 2015 to 2017 [20,48-50]. A Puerto Rican, Ramón Cruz, is currently a member of the Sierra Club's Board of Director [51]. There have been other high-profile hires at the Vice-Presidential level also. In 2017, the National Audubon Society hired a Black female, Deeohn Ferris, to be their Vice President for Equity, Diversity, and Inclusion [52]. The Environmental Defense Fund also hired a Cuban-American, Jorge Consuegra, to be their Chief Diversity Officer in 2017. Other high-profile hires of people of color include the National Wildlife Federation's hiring of Mustafa Santiago Ali as the Vice President of Environmental Justice, Climate, and Community Revitalization for the National Wildlife Federation [53]. Despite these appointments, there is still a need to track and report on progress toward enhancing the diversity in environmental organizations.

Since 2014 and the unveiling of the GuideStar portal to disclose diversity data of environmental nonprofits, there has been a limited assessment of the extent to which enviros are using the system to reveal their demographic characteristics. Green 2.0 has tracked the submission of diversity data of the 40 largest environmental nonprofits and foundations. The group reported that more than 25 of the most prominent environmental groups and eight major environmental funders had revealed their demographic characteristics on GuideStar by Earth Day 2015 [54]. A year later, Green 2.0 announced 
that another six of the top 40 environmental organizations had released their diversity information through GuideStar [55]. Though Green 2.0 tracks the reporting of the top 40 organizations, this tells us nothing about how environmental organizations that are outside of the top 40 are using the system. A 2018 study that examined 2057 environmental nonprofits found that $6.8 \%$ of the sample revealed gender diversity data, 3.9\% reported racial diversity data, and 0.7\% disclosed LGBTQ data [56].

\subsection{Social Responsibility and Social Sustainability}

The focus on diversity is appropriate, as research shows that it is an essential dimension of institutional life. In a 2017 survey of more than 10,000 human resources professionals and business leaders from 140 countries, $69 \%$ of the executives rated diversity and inclusion as a vital issue. In the same survey, $38 \%$ of the executives reported that the primary sponsor of their company's diversity and inclusion efforts was the Chief Executive Officer (CEO) [23].

Diversity, equity, and inclusion are forms of social responsibilities that further the social sustainability of organizations. Environmental nonprofits are no exception. Scholars argue that social equity goes hand in hand with environmental protection and sustainability. However, researchers have paid scant attention to social sustainability and social responsibility in environmental organizations. Consequently, we will draw on relevant scholarly literature from the field of corporate social responsibility and corporate social sustainability to inform this discussion.

A recent study of corporations found that though firms consider social sustainability in order to attract new workers, corporations place a low emphasis on it and do not consider it as essential as they do environmental sustainability. Hence, efforts to incorporate social sustainability initiatives are sometimes symbolic rather than substantive $[57,58]$. However, other scholars argue that, increasingly, firms pay attention to social responsibility and see it as a mechanism to gain a competitive edge $[59,60]$. There is also increased pressure on corporations to inform the public about social responsibility activities. As a result, researchers find that corporations are reporting their social engagement data at increasing levels.

There is a link between diversity and social responsibility. Researchers find that gender has a positive impact on the disclosure of social responsibility data. That is, the higher the number of females in supervisory positions like boards, the higher the rate of reporting of environmental and social responsibility data [60-62]. Research also shows that the higher the number of women on the board, the more likely it is that a corporation reports diversity data [63].

\section{Methodology}

\subsection{Data Collection}

This paper reports the findings of an analysis of organizational disclosure of diversity data. It is a national study of 12,054 small, medium-sized, and large environmental nonprofits. This is one of the largest samples of environmental organizations studied in the United States. The study uses a multi-method approach that involves collecting organizational data from government and other public sources, as well as spatial and descriptive statistical analyses.

These data were inputted and analyzed in Statistical Package for the Social Sciences (SPSS) 25.0 [64]. The data were collected over 19 months from January 2018 to July 2019. We collected information on the factors shown in List 1 in order to answer the questions posed above. We also obtained data on the compensation of top executives and other senior staff. However, it is beyond the scope of this paper to discuss staff compensation; this material will be the topic of future articles. Related research on the types of diversity activties that environmental nonprofits undertake and the effectiveness of such undertakings is underway. However, these findings will not be presented or discussed here as, these too, are beyond the scope of the current article.

List 1: Variables Examined.

Dependent Variables 
1. Report any kind of diversity data

2. Report gender data

3. Report race/ethnicity data

4. Report LGBTQ data

\section{Independent Variables}

1. State or territory located in

2. Region located in

3. Urban, suburban, and rural locations

4. Type of environmental nonprofit

5. Annual organizational revenue

6. Number of staff

7. Number of board members

8. Gender of the top executive

9. Race/ethnicity of the top executive

10. Year of Guide Star profile.

\subsubsection{Data Sources and Organizational Selection}

Data were collected from GuideStar Premium [65], ProPublica's Nonprofit Explorer [66], Charity Navigator [67], the Internal Revenue Service (IRS) Form 990, Form 990-EZ, Form 990-PF, and Form 990-N [68], and from environmental organizations' websites, Facebook, Twitter, and related LinkedIn pages. The two main search engines used were GuideStar and ProPublica, but other sources named above were utilized to supplement the information gleaned from the primary search engines. GuideStar and ProPublica attach the organization's latest tax forms to the nonprofit's profiles. GuideStar also displays the demographic data of institutions that revealed them.

Relevant organizations were identified by using search terms such as "environmental quality," "environmental protection," "environment and animals," "conservation," "sustainability," "energy," "environmental justice," and "zoos and aquarium." This approach yielded organizations that were not environmental organizations; such organizations were expunged from our database.

\subsubsection{Obtaining Financial Information for Organizations}

To maintain their nonprofit status, organizations must file a version of Form 990 with the IRS each year. These forms are available to the public. The most commonly-available tax forms were from 2015-2017-80.1\% of the forms available were from these years. We also looked at the type of tax forms filed by organizations and eliminated institutions that did not provide enough information to meet the needs of the study. Nonprofit organizations can file different types of tax forms depending on their revenues as well as the type and purpose of the organizations. The institutions in the study could file either Form 990, Form 990-EZ, Form 990-PF, or Form 990-N.

Each of these forms collects different information from the submitter. Institutions with revenues of $\$ 50,000$ or less in a year are eligible to file a Form $990-\mathrm{N}$. However, the $990-\mathrm{N}$ contains very little information about the organization; does not provide a detailed line-item listing of revenues, expenditures, or assets; does not list the number of employees or board members, and does not list the name of the senior staff and board members, nor their compensation levels [69]. Furthermore, nonprofits that were eligible to file a 990-N typically had a rudimentary or non-existent Web presence; it was also rare that such organizations had a GuideStar profile. Consequently, if an organization filed only $990-N s$ since 2008 , they were excluded from the study. If an organization has gross receipts less than $\$ 200,000$ or total assets less than $\$ 500,000$, it is eligible to file the 990-EZ. Private foundations, regardless of size, file a 990-PF. All other nonprofits file a Form 990 [69]. While these three forms provide 
slightly different information in different parts of the tax form, they all provide enough information for the research needs of this study.

\subsection{Organization Typology}

The National Taxonomy of Exempt Entities (NTEE) codes were used in the initial classification of environmental nonprofits. NTEE codes are used by the IRS to classify nonprofit organizations [70]. GuideStar, ProPublica, and Charity Navigator use the NTEE codes to organize institutions in their databases. Though organizations may select major and minor categories to describe themselves, one cannot rely solely on the classification codes assigned to the environmental profits that are contained in the databases of GuideStar, ProPublica, and Charity Navigator and similar repositories of nonprofit information for research purposes. We checked the classification of each organization downloaded and found more than 600 organizations that were labeled as environmental quality, protection, and beautification even though they were not environmental organizations. Another common type of misclassification occurred when organizations mentioned activities like recycling that they organized or hosted. Hence, we discovered that several nature centers that taught kids about recycling were categorized as recycling centers rather than nature centers. There was also a tendency to classify nonprofits that have environmental-sounding names as environmental entities even though they may be a church missionary group, spiritual retreat, a pet-adoption program, pre-school, or school sports team. Such organizations were excluded from our dataset.

We developed a typology that contains 34 different categories of organizations. Nonprofits were placed in one of these categories based on their primary mission and focus. Mission statements, available on GuideStar as well as on the websites and social media portals of organizations, were also used to inform how organizations were classified. Our classification includes categories such as environmental justice and environmental media that are not in the NTEE codes.

\subsection{Defining Regions}

For this study, the nonprofits are assigned to one of eight regions. The states and territories contained in each region are listed in Table 1.

Table 1. States and Territories Contained in Each Region.

\begin{tabular}{ll}
\hline 1. New England & Maine, New Hampshire, Vermont, Massachusetts, Connecticut, Rhode Island \\
\hline 2. Mid-Atlantic & New York, New Jersey, Pennsylvania, Delaware, Maryland, Virginia \\
\hline 3. Southeast & North Carolina, South Carolina, Georgia, Florida, Puerto Rico, U.S. Virgin Islands \\
\hline 4. Midwest & Ohio, Michigan, Indiana, Illinois, Wisconsin, Iowa, Minnesota \\
\hline 5. South & West Virginia, Kentucky, Tennessee, Alabama, Mississippi, Louisiana, Arkansas, Missouri \\
\hline 6. Plains-Mountain & North Dakota, South Dakota, Nebraska, Wyoming, Montana, Idaho \\
\hline 7. Southwest & Kansas, Oklahoma, Texas, New Mexico, Colorado, Utah, Arizona, Nevada \\
\hline 8. Pacific & Alaska, Washington, Oregon, California, Hawaii, Micronesia, Marianas \\
\hline
\end{tabular}

\subsection{Urban, Suburban, and Rural Designations}

We used U.S. Census Bureau guidelines to classify urban and rural areas. According to the census, an urbanized area is a continuously built-up setting with a population of 50,000 or more. The bureau classifies an urban place outside of an urban center or central city as one that is incorporated with a population of at least 2500 residents but less than 50,000 inhabitants. We refer to these locales as suburban. The third category-referred to as extended city by the census—describes incorporated locales containing large expanses of sparsely populated areas that are distinct from cities or rural areas. The final category, rural areas, are incorporated entities or census designated places that have fewer than 2500 inhabitants; these are not located in urban areas [71,72]. Because there were only 14 extended 
cities in our sample, we combined extended cities (very small stand-alone towns) with rural areas. We refer to this combined group as rural.

\subsection{Spatial Mapping Techniques}

The SPSS data file was converted to a comma separated values (CSV) file in order to create spatial maps generated from Geographic Information Systems (GIS) software. The CSV was uploaded into ArcGIS Online [73]. ArcGIS Online creates a spatial file by geocoding the addresses in the file. Geocoding is the process by which addresses are converted into geographic coordinates. The geocoding results in a hosted feature layer in ArcGIS Online which is transformed into a shapefile. The shapefile is downloaded for further analysis outside of ArcGIS Online.

Next, we uploaded the shapefile into ArcMap version 10.6.1 [74]. We obtained the administrative areas (boundaries) for the United States as well as the following territories-Puerto Rico, the U.S. Virgin Islands, and the Commonwealth of the Northern Mariana Islands-in shapefile format from Tiger/Line shapefiles. The administrative areas for the Federated States of Micronesia were obtained from DIVA-GIS [75]. The locations of environmental nonprofits in the continental United States, Alaska, Puerto Rico, and the U.S. Virgin Islands were projected in each map using the North America Albers Equal Area Conic Projected Coordinate System. Hawaii and the Commonwealth of the Northern Mariana Islands were projected in each map using WGS 1984 Web Mercator (Auxiliary Sphere) Projected Coordinate System [76]. The Federated States of Micronesia is projected in each map using the Pohnpei Geographic Coordinate System (GCS) [77]. The organizations are displayed by location in all maps. However, because some organizations are close to others, the dots overlapped at times.

\section{Results}

\subsection{Disclosure of Diversity Data: A National Overview}

This paper analyzes 12,054 environmental nonprofits to see the extent to which these organizations disclose demographic data on their staff and boards. The analysis takes the form of crosstabulations to explore bi-variate relationships. As Table 2 shows, 449 or $3.7 \%$ of the organizations revealed diversity data. In essence, 11,605 or $96.3 \%$ of the organizations did not reveal any diversity data. Regarding the disclosure of specific types of diversity data, 3.7\% disclosed their gender data, 2.1\% their racial/ethnic data, and $0.3 \%$ their LGBTQ data. Figure 1 shows the locations of all the organizations studied, and Figure 2 shows the location of the nonprofits that shared their data.

Table 2. Environmental Nonprofits' Reporting of their Staff or Board Diversity Data.

\begin{tabular}{cccc}
\hline Staff Diversity & $\begin{array}{c}\text { Number of } \\
\text { Organizations }\end{array}$ & $\begin{array}{c}\text { Number that } \\
\text { Report Data }\end{array}$ & $\begin{array}{c}\text { Percent that } \\
\text { Report Data }\end{array}$ \\
\hline Report any type of staff or board diversity data & 12,054 & 449 & 3.7 \\
Report gender of the staff or board & 12,054 & 449 & 3.7 \\
Report race/ethnicity of the staff or board & 12,054 & 253 & 2.1 \\
Report LGBTQ data about the staff or board & 12,054 & 33 & 0.3 \\
\hline
\end{tabular}

Figure 3 indicates that organizations are more likely to reveal their gender diversity data than either their racial/ethnic or LGBTQ data. While all 449 organizations that disclosed demographic data revealed gender data, only 253 or $56.3 \%$ of those disclosing diversity data reveal racial data. A much smaller number and percentage revealed LGBTQ data. The figure shows that only 33 organizations or $7.3 \%$ of those reporting diversity data divulge LGBTQ data. However, the LGBTQ data might be an undercount as GuideStar only shows the LGBTQ data for organizations that have 15 or more employees. GuideStar does this "to protect the identity of individuals" [35]. Hence, organizations with smaller staff might have disclosed LGBTQ data, but that information is not relayed to the public 
by GuideStar's management. GuideStar uses the same policy to guide the disclosure of disability data. This study did not assess the revelation of disability data because few organizations revealed this data.

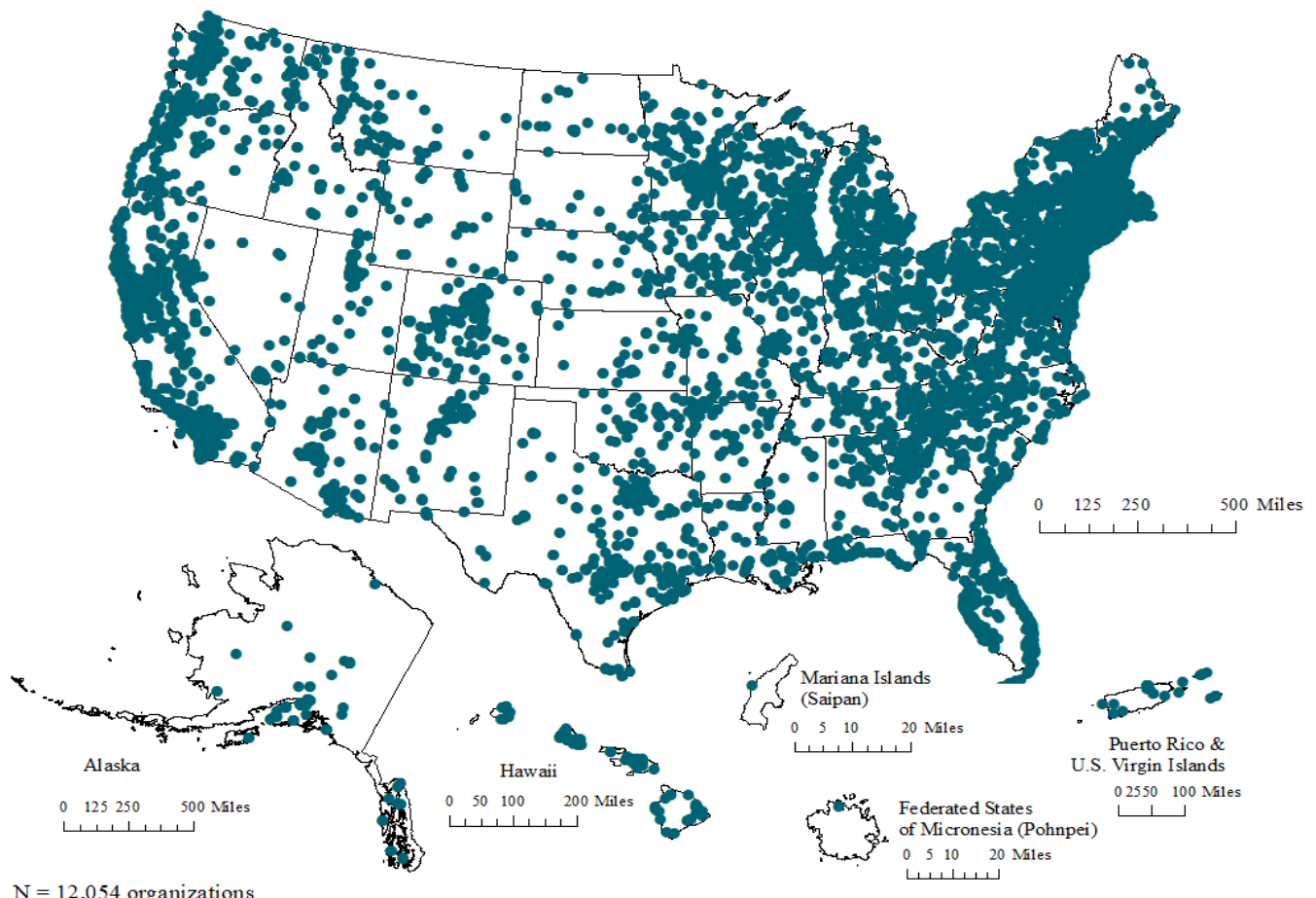

Figure 1. The Locations of All Organizations Studied.

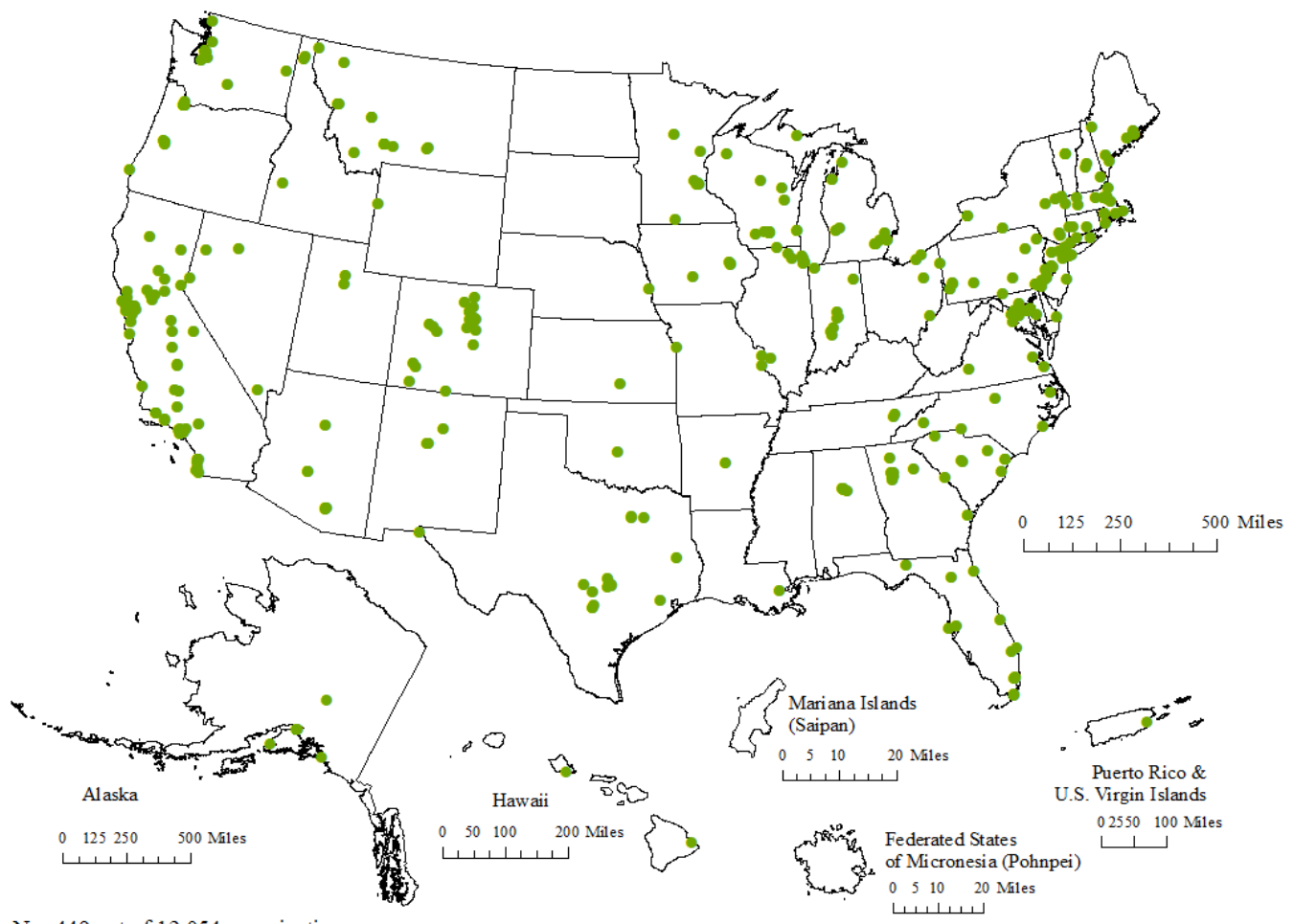

$\mathrm{N}=449$ out of 12,054 org anizations

Figure 2. The Locations of Organizations that Reported Any Type of Diversity Data. 


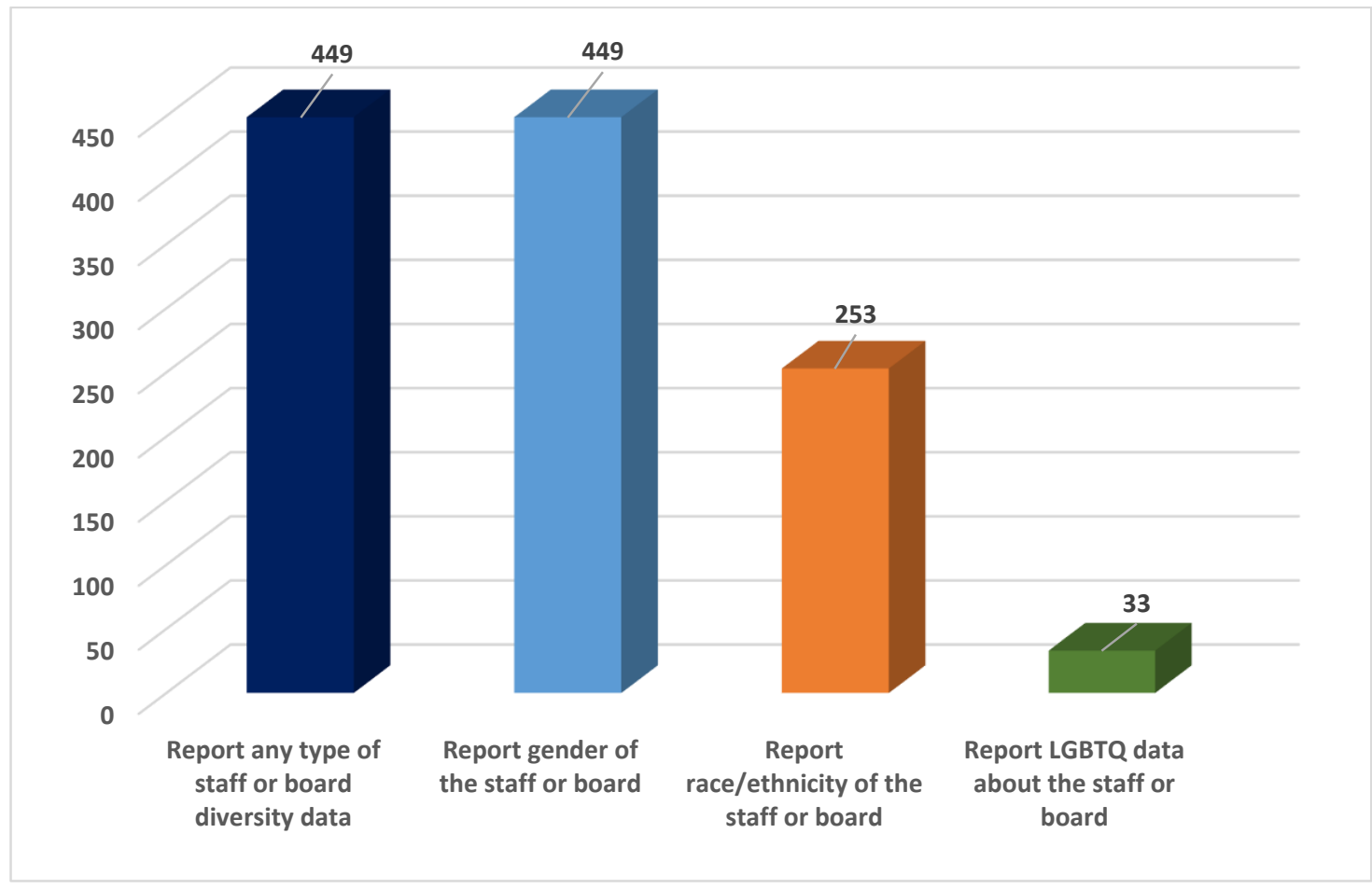

Figure 3. Number of Environmental Organizations that Report Diversity Data.

\subsection{Regional Variations in the Disclosure of Demographic Data}

Reporting varied in the eight regions studied; it ranged from a high of $4.7 \%$ of the organizations in the Mid-Atlantic region revealing their diversity data to a low of $1.2 \%$ of the organizations in the South doing likewise (Table 3). Most of the organizations that disclose diversity data are in two regions-the Pacific (117 nonprofits) and the Mid-Atlantic (108 nonprofits). In contrast, only ten of the 808 organizations studied in the South revealed their diversity data.

Table 3. Regional Variations in the Reporting of Diversity Data in Environmental Nonprofits.

\begin{tabular}{|c|c|c|c|c|c|}
\hline Region & $\begin{array}{c}\text { Number of } \\
\text { Organizations } \\
\text { Studied }\end{array}$ & $\begin{array}{c}\text { Number of } \\
\text { Organizations } \\
\text { Reporting Data }\end{array}$ & $\begin{array}{l}\text { Percent } \\
\text { Reporting } \\
\text { Gender }\end{array}$ & $\begin{array}{c}\text { Percent } \\
\text { Reporting } \\
\text { Race/Ethnicity }\end{array}$ & $\begin{array}{c}\text { Percent } \\
\text { Reporting } \\
\text { LGBTQ }\end{array}$ \\
\hline Pacific & 2627 & 117 & 4.5 & 2.7 & 0.3 \\
\hline Mid-Atlantic & 2290 & 108 & 4.7 & 3.1 & 0.6 \\
\hline Midwest & 1837 & 61 & 3.3 & 1.9 & 0.3 \\
\hline Southwest & 1492 & 59 & 4.0 & 2.1 & 0.2 \\
\hline New England & 1296 & 36 & 2.8 & 1.2 & 0.2 \\
\hline Southeast & 1223 & 38 & 3.1 & 1.3 & 0.1 \\
\hline South & 808 & 10 & 1.2 & 0.6 & 0.1 \\
\hline Plains-Mountain & 481 & 20 & 4.2 & 2.1 & 0.0 \\
\hline
\end{tabular}

Figure $4 \mathrm{a}-\mathrm{h}$ show each region and the location of each nonprofit that report their diversity data. See Appendix A.

Figures A1-A8 for maps showing the loctaion of organizations that did not reveal any diversity data. The environmental nonprofits that do divulge their diversity data are not dispersed evenly within the regions. Hence, distinct clusters are visible within the regions. In the Pacific, for instance, 
reporting organizations are clustered around Anchorage, Seattle, San Francisco Bay, Los Angeles, San Diego, and along the Interstate 5 Corridor.

Many of the reporting organizations in the Mid-Atlantic region are along the Interstate 95 Corridor. Washington D.C., New York, Philadelphia, Northern New Jersey, and Northern Virginia host the most organizations that divulge diversity data. While there are few organizations in Upstate New York or in southern and western parts of Virginia that disclose diversity data, reporting organizations are in the southern portion of Pennsylvania stretching from Pittsburgh to Philadelphia.

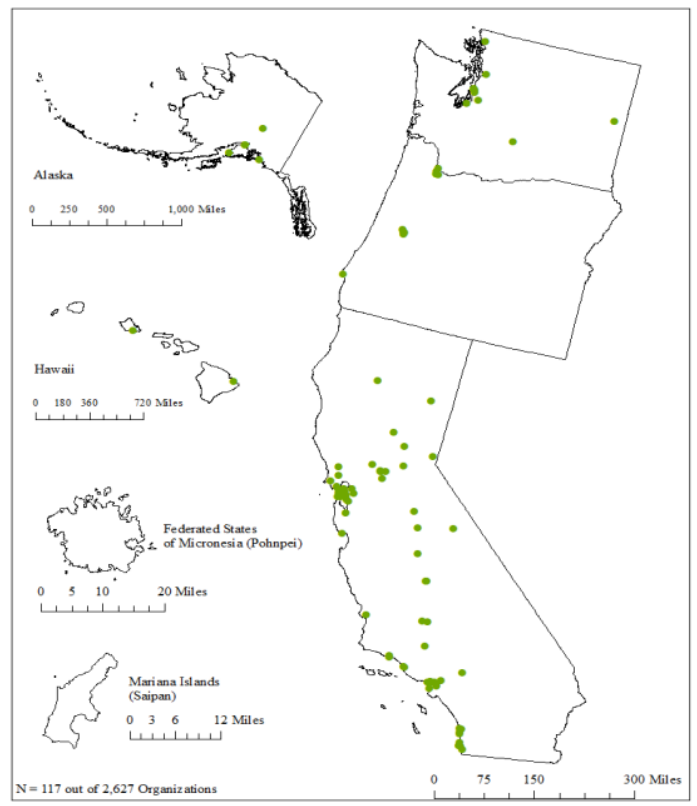

(a) Pacific Region.

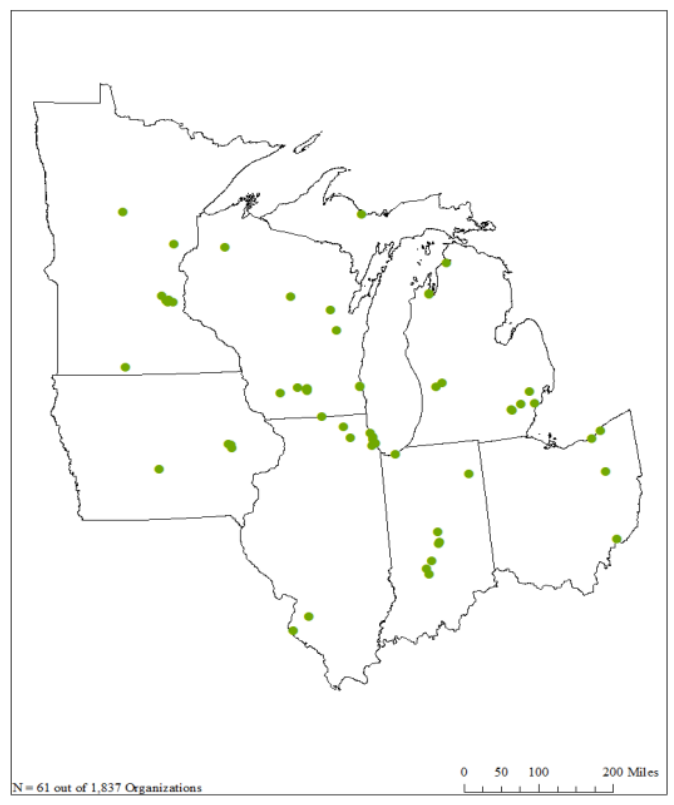

(c) Midwest Region

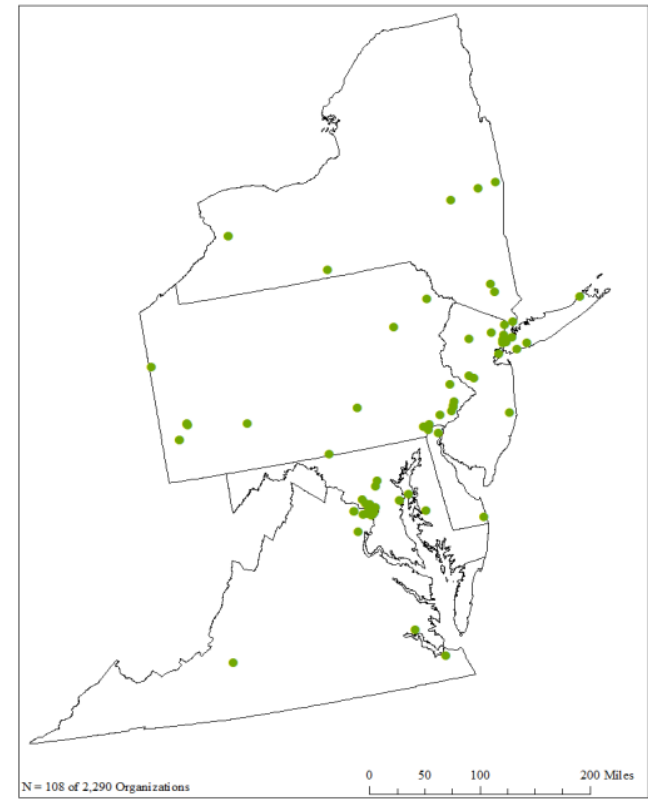

(b) Mid-Atlantic Region

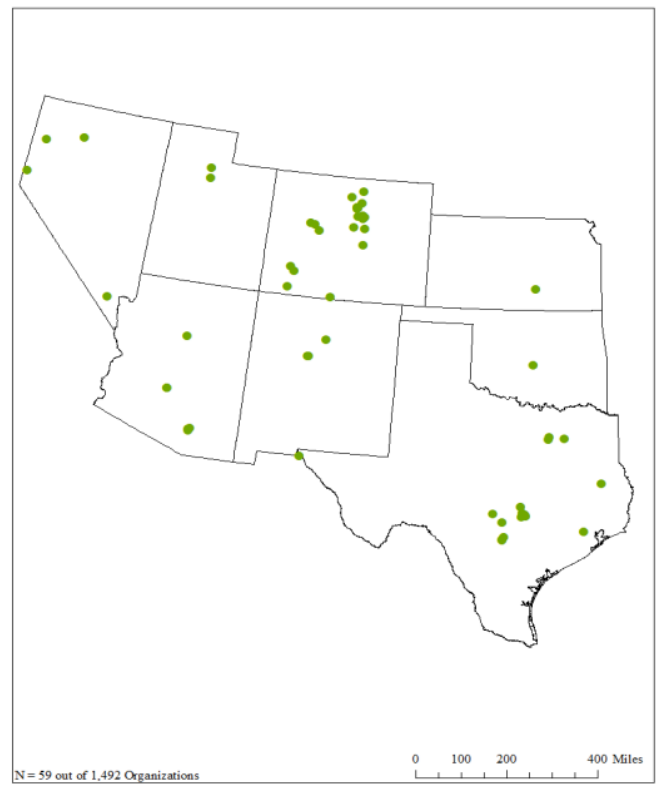

(d) Southwest Region

Figure 4. Cont. 


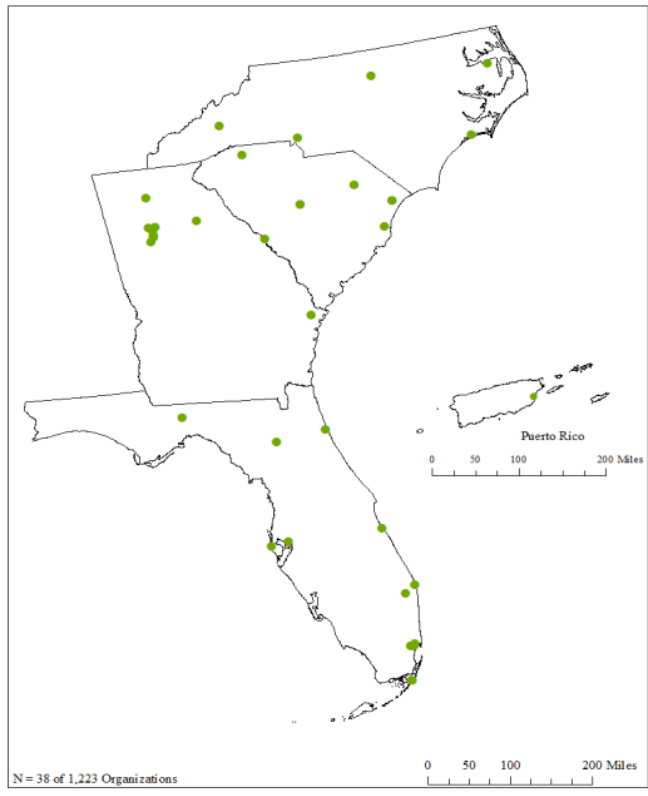

(e) Southeast Region

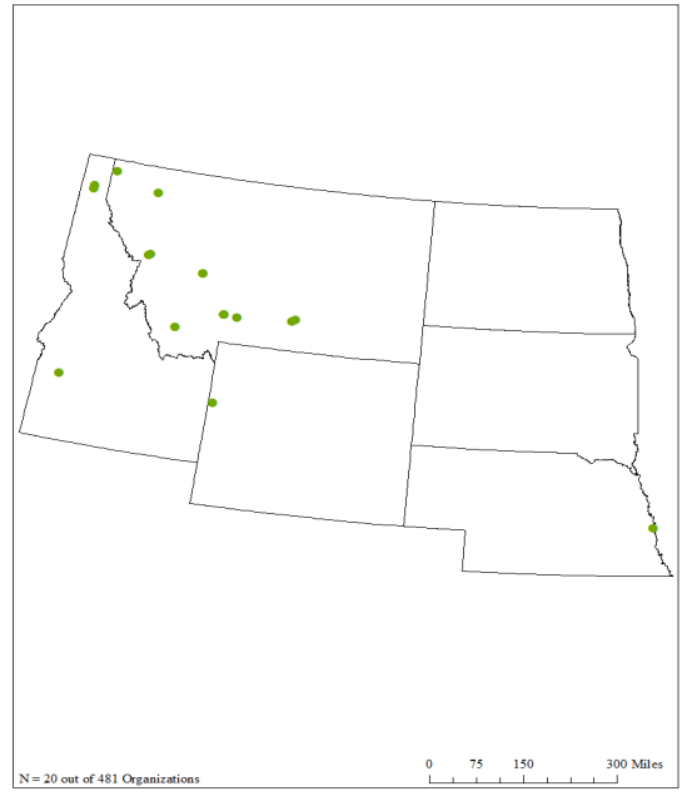

(g) Plains-Mountain Region

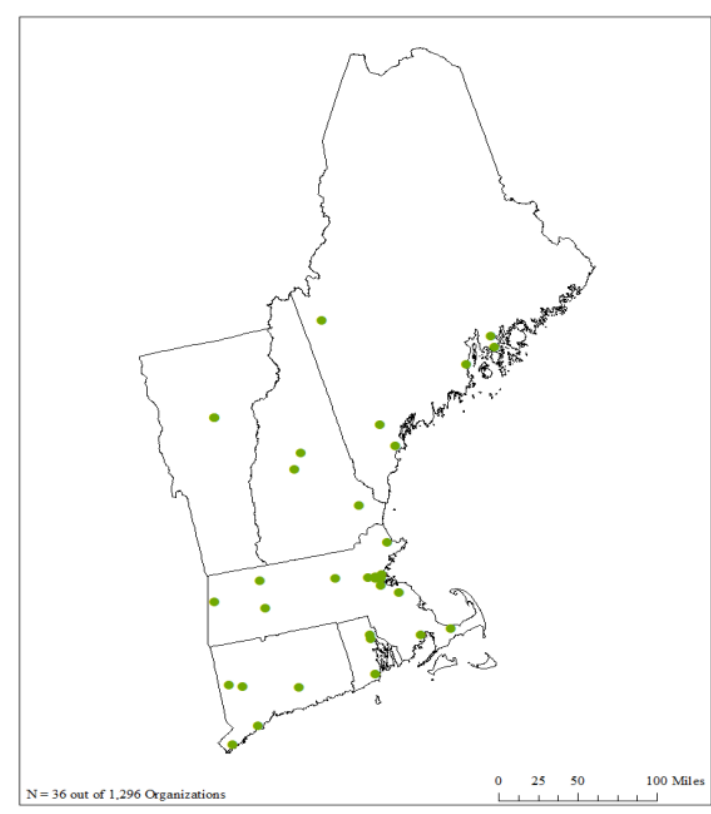

(f) New England Region

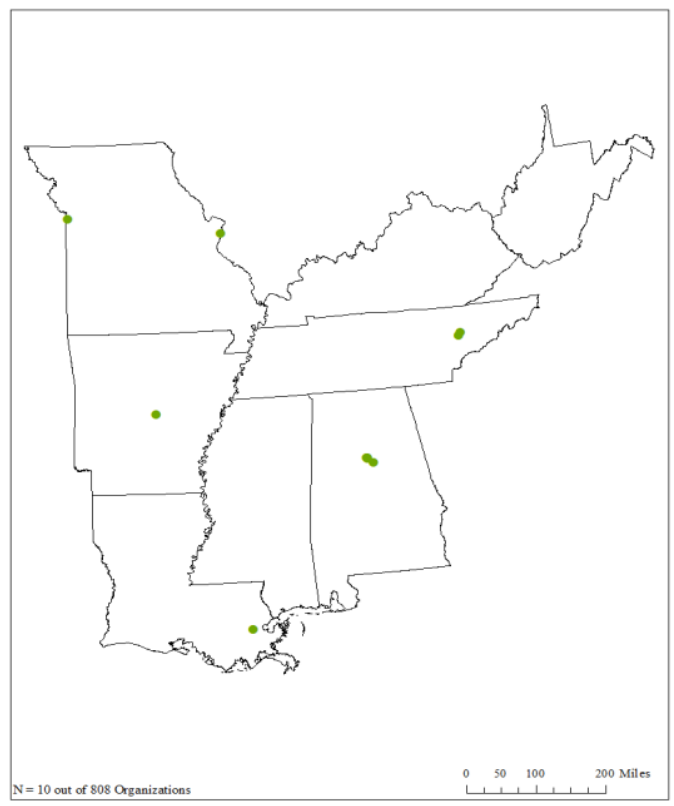

(h) South Region

Figure 4. Organizations that Report Diversity Data.

In the Midwest, reporting organizations are in metropolitan areas such as Cleveland, Detroit, Indianapolis, Chicago, and Minneapolis. Two of the Great Lakes (Lake Erie and Lake Michigan), as well as the Mississippi River, are the focal points of reporting as organizations that disclose their diversity data are arrayed along or close to the shores and banks of these significant freshwater sources.

The Southwest region ranks fourth in terms of the number of environmental nonprofits that divulge their diversity data. Colorado and Texas are the two states in the region that have the most significant number of reporting organizations. In Colorado, most of the reporting organizations are in the Denver and Boulder areas. In Texas, reporting institutions are found around Dallas, Austin, and Houston. As was the case in the Pacific region wherein environmental organizations located along the border with Mexico reported diversity data, the same phenomenon is observable in the Southwest. 
The highest concentration of reporting in the Southeast Region occurs in and around Atlanta. There is a belt of reporting that spreads eastward from Atlanta, across South Carolina to the coast. Reporting organizations in Florida are around the coastal areas of the state. While there is one reporting organization in Puerto Rico, there is none in the U.S. Virgin Islands.

Most of the New England organizations that disclose diversity data are in the Boston metropolitan area. There was also reporting across Massachusetts that extended from Boston west along the Interstate 90 Corridor. None of the organizations studied in the northeastern portion of Maine reported any diversity data. There was no reporting in most of New Hampshire and Vermont either. Reporting organizations in Rhode Island are clustered around Providence while reporting was evident in the southwestern portion of Connecticut.

Except for one reporting organization in Omaha, all the organizations that disclose diversity data in the Plains-Mountain Region are in the northwestern part of the region. More specifically, the bulk of these organizations are in the western part of Montana. None of the 75 organizations studied in two of the Plains states-North Dakota and South Dakota—reported any diversity data. Three of the five states that did not report any diversity data are in the South. That is, none of the 203 organizations studied in West Virginia, Kentucky, and Mississippi reported any diversity data. Unlike other regions, there are no large clusters of reporting organizations visible in the South.

\subsection{State and Territories and Variations in the Reporting of Demographic Data}

By far, the most significant number of organizations studied, and the largest number of organizations disclosing diversity data are in California (Table A1). Of the 1543 organizations studied in California, 82 reported their diversity data. Thirty organizations in New York and 29 in Washington, D.C. divulged diversity data also. Colorado (25) and Pennsylvania (20) round out the five states and district which contained 20 or more reporting institutions. Between 10 and 16 organizations revealed their diversity data in an additional 12 states. Therefore, in 36 of the states and territories studied, less than ten organizations disclosed any diversity data.

Figure A9 shows the percentage of organizations in each state and territory that divulged diversity data. By far, the highest percentage of organizations reporting their diversity data are in Washington, D.C.; $12.3 \%$ of the organizations in the nation's capital disclosed their diversity data. Similarly, $8.6 \%$ of the organizations studied in Montana, and $6.2 \%$ of those studied in Colorado revealed their diversity data. Five percent or more of the organizations in California, Puerto Rico, and Georgia also reported their diversity data. On the other hand, less than $2 \%$ of the organizations in the remaining states and territories disclosed any diversity data.

\subsection{Urban, Suburban, and Rural Variations}

The disclosure of demographic data is highest in urban areas and lowest in rural locales. While $5 \%$ of the urban environmental nonprofits reveal their demographic data, $2.9 \%$ of those in the suburbs, and $2.3 \%$ of those in rural areas do likewise (Table 4). When only the 449 organizations that revealed diversity data are considered, $59.2 \%$ of those reporting diversity data were located in urban areas, $31.4 \%$ in the suburbs, and the remaining $9.4 \%$ were rural.

Table 4. Urban-Rural Variations in the Reporting of Diversity Data in Environmental Nonprofits.

\begin{tabular}{cccccc}
\hline $\begin{array}{c}\text { Level of } \\
\text { Urbanization }\end{array}$ & $\begin{array}{c}\text { Number of } \\
\text { Organizations } \\
\text { Studied }\end{array}$ & $\begin{array}{c}\text { Number of } \\
\text { Organizations } \\
\text { Reporting Data }\end{array}$ & $\begin{array}{c}\text { Percent } \\
\text { Reporting } \\
\text { Gender }\end{array}$ & $\begin{array}{c}\text { Percent } \\
\text { Reporting } \\
\text { Race/Ethnicity }\end{array}$ & $\begin{array}{c}\text { Percent } \\
\text { Reporting } \\
\text { LGBTQ }\end{array}$ \\
\hline Rural & 1824 & 42 & 2.3 & 1.3 & 0.1 \\
\hline Suburban & 4918 & 141 & 2.9 & 1.7 & 0.1 \\
\hline Urban & 5312 & 266 & 5.0 & 2.8 & 0.5 \\
\hline
\end{tabular}


Urban environmental nonprofits are more likely to reveal gender, race/ethnicity, and LGBTQ data than suburban and rural organizations. A total of 42 rural, 141 suburban, and 266 urban nonprofits shared data on gender diversity. When it came to race/ethnicity, only 24 rural environmental organizations and 82 suburban nonprofits divulged this kind of information. In contrast, 147 (or 58.1\%) of the organizations reporting race/ethnicity data were located in urban areas. Only one rural environmental nonprofit and six suburban ones disclosed their LGBTQ data. The remaining 26 that reported LGBTQ data were urban.

\subsection{The Relationship Between Organizational Type and the Disclosure of Demographic Data}

In total 34 different types of environmental organizations were studied. The largest group in the sample was water resources, wetlands conservation, and management organizations. Of the 2040 water resources organizations studied, 69 revealed their diversity data. See Table A2. Fifty-two of the 788 natural resources conservation and protection organizations also revealed their diversity data, so did 48 of the 1,618 land resources conservation organizations studied. Twenty-two of each of the energy resources conservation and sustainable development, forest conservation organizations, and 21 environmental justice organizations divulged diversity data. Twenty-one of environmental education, outdoor survival, and nature centers also divulged their demographic information. None of the 98 management and technical assistance organizations divulged any diversity data; this was the only organizational type with no disclosure of data.

Figure A10 shows that the level of reporting ranged from $0 \%$ to $13.4 \%$ in the different types of environmental nonprofits. Environmental justice organizations were the most likely to report their diversity data; $13.4 \%$ of them did. Environmental health organizations were next- $10.3 \%$ of them revealed their diversity data. Environmental justice organizations were more than twice as likely as natural resources conservation institutions and waste management organizations to release diversity data.

Energy resources conservation and sustainable development (4.4\%) and sustainability organizations $(4.2 \%)$ were roughly three times less likely than environmental justice organizations to disclose their diversity data. When it comes to reporting diversity data, energy resources organizations ranked 14th and sustainability organizations ranked 15th among the 34 types of organizations studied. Less than $2 \%$ of the botanical, horticultural, and landscape services; environmental beautification and aesthetics; natural history, historic preservation, and heritage organizations; garden clubs and horticultural programs; and management and technical assistance organizations revealed any diversity data.

\subsection{The Size of Organizational Revenue and the Disclosure of Demographic Data}

The study examined two indicators of size: (a) The organization's revenue; and (b) the number of staff an organization has. Both indicators show that generally speaking, size is positively associated with the disclosure of organizational diversity data. Table 5 shows the number of organizations studied in each revenue category. For 801 of the organizations in the sample, the total revenue for the tax year on file was either undisclosed, the organizations had deficits, or there were no revenues to report. For other organizations, revenues ranged from less than $\$ 100$ to more than $\$ 20$ million. One hundred and forty-two of the 1377 organizations that had revenues in the $\$ 1,000,001-\$ 5,000,000$ range revealed diversity data. More than a hundred of the organizations that had revenues of $\$ 100,001-\$ 500,000$ also reported their diversity data.

Figure 5 illustrates how the size of the total revenue is related to the percentage of organizations that divulge diversity data. The graph shows that the higher the revenue, the more likely it is that organizations reveal all three types of diversity data studied. The rate of reporting increases steadily up to $\$ 20$ million in revenues, but after that, there is a dramatic increase in reporting in organizations with the highest revenues. The increased reporting is most evident for the disclosure of racial/ethnic diversity data. 
Table 5. Organizational Revenue and Variations in the Reporting of Diversity Data.

\begin{tabular}{cccccc}
\hline Revenue & $\begin{array}{c}\text { Number of } \\
\text { Organizations } \\
\text { Studied }\end{array}$ & $\begin{array}{c}\text { Number of } \\
\text { Organizations } \\
\text { Reporting Data }\end{array}$ & $\begin{array}{c}\text { Percent } \\
\text { Reporting } \\
\text { Gender }\end{array}$ & $\begin{array}{c}\text { Percent } \\
\text { Reporting } \\
\text { Race/Ethnicity }\end{array}$ & $\begin{array}{c}\text { Percent } \\
\text { Reporting } \\
\text { LGBTQ }\end{array}$ \\
\hline $\begin{array}{c}\text { Undisclosed, No } \\
\text { Revenue, Deficit }\end{array}$ & 801 & 10 & 1.2 & 0.2 & 0.0 \\
\hline$\$ 1-\$ 100,000$ & 5607 & 50 & 0.9 & 0.6 & 0.0 \\
\hline$\$ 100,001-\$ 500,000$ & 2864 & 103 & 3.6 & 1.9 & 0.0 \\
\hline$\$ 500,001-\$ 1,000,000$ & 914 & 67 & 7.3 & 3.9 & 0.4 \\
\hline$\$ 1,000,001-\$ 5,000,000$ & 1337 & 142 & 10.3 & 5.4 & 1.1 \\
\hline$\$ 5,00,0001-\$ 10,000,000$ & 232 & 26 & 11.2 & 6.0 & 1.7 \\
\hline$\$ 10,000,001-\$ 20,000,000$ & 119 & 15 & 12.6 & 6.7 & 2.5 \\
\hline$\$ 20,000,001$ or more & 140 & 36 & 25.7 & 22.9 & 4.3 \\
\hline
\end{tabular}

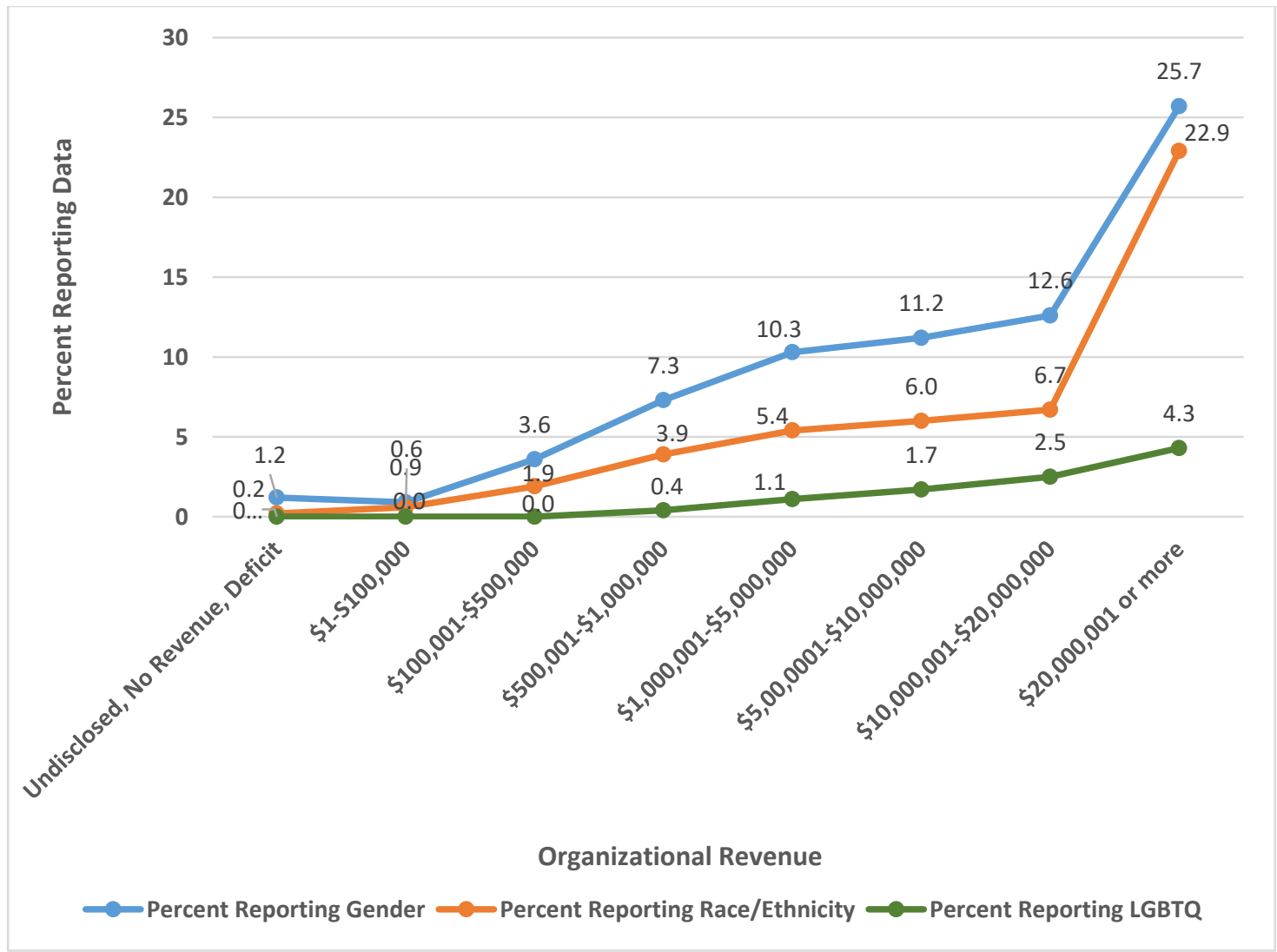

Figure 5. Size of Organizational Revenue and the Reporting of Diversity Data.

\subsection{The Size of Organizational Staff and the Reporting of Demographic Data}

Table 6 shows that 70 of the 7881 organizations for which the number of staff were undisclosed and unknown, revealed the diversity data. Also, 176 of the 2562 organizations with a small staff (1-9 employees) divulged demographic data. Three hundred and thirty-six organizations had 50 or more staff; of these, 47 disclosed demographic data.

So, for the reporting of gender and LGBTQ data, the percentage of organizations reporting such data almost doubles as it goes from organizations with revenues of $\$ 10,000,001-\$ 20$ million to those with more than $\$ 20$ million in revenues. The increase in reporting is most dramatic in the reporting of race/ethnicity data-the level of reporting jumps from $6.7 \%$ of the organizations in the 
$\$ 10,000,001-\$ 20$ million range reporting to $22.9 \%$ of those with more than $\$ 20$ million in revenues reporting. The increase in reporting race/ethnicity data is more than triples in this one interval.

Table 6. Size of Staff and Variations in the Reporting of Diversity Data.

\begin{tabular}{cccccc}
\hline Size of Staff & $\begin{array}{c}\text { Number of } \\
\text { Organizations } \\
\text { Studied }\end{array}$ & $\begin{array}{c}\text { Number of } \\
\text { Organizations } \\
\text { Reporting Data }\end{array}$ & $\begin{array}{c}\text { Percent } \\
\text { Reporting } \\
\text { Gender }\end{array}$ & $\begin{array}{c}\text { Percent } \\
\text { Reporting } \\
\text { Race/Ethnicity }\end{array}$ & $\begin{array}{c}\text { Percent } \\
\text { Reporting } \\
\text { LGBTQ }\end{array}$ \\
\hline $\begin{array}{c}\text { Undisclosed, } \\
\text { Unknown, } \\
\text { None }\end{array}$ & 7881 & 70 & 0.9 & 0.4 & 0.0 \\
\hline $1-9$ & 2562 & 176 & 6.9 & 3.7 & 0.2 \\
\hline $10-49$ & 1274 & 156 & 12.2 & 7.1 & 7.5 \\
\hline $50-99$ & 170 & 22 & 12.9 & 12.6 & 2.4 \\
\hline $100-499$ & 135 & 20 & 14.8 & 16.1 & 3.7 \\
\hline 500 or More & 31 & 5 & 16.1 & 0.0 \\
\hline
\end{tabular}

Figure 6 shows how the size of the staff is related to the reporting of diversity data. For the reporting of gender and race/ethnicity data, the larger the size of the staff, the greater the tendency to reveal these two types of diversity data. While $6.9 \%$ of the organizations that have 1-9 employees revealed their gender data, $16.1 \%$ of those that had 500 or more staff did. The reporting of race/ethnicity data has a different pattern. That is, $3.7 \%$ of the organizations that have 1-9 employees report race/ethnicity data. Hence, small organizations were more than twice as likely to report gender than race/ethnicity data. The level of reporting of race/ethnicity data stays flat at $7.1 \%$ for organizations that have between 10 and 99 employees. However, the percentage of organizations that report race/ethnicity data is more than double from this level when organizations have more than 500 employees. In other words, the percentage increases from $7.1 \%$ to $16.1 \%$.

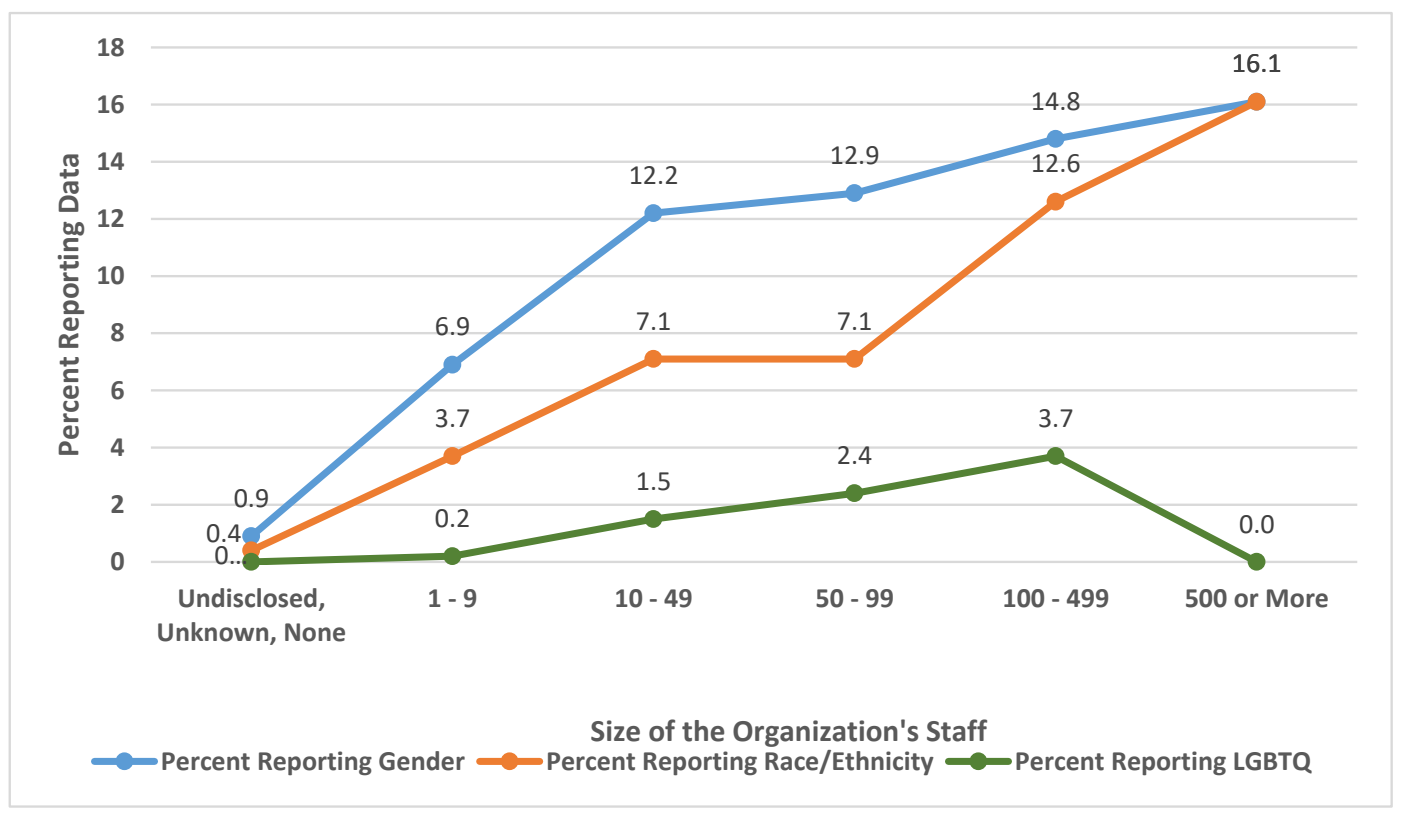

Figure 6. Size of the Organization's Staff and Reporting of Diversity Data.

The pattern of reporting of LGBTQ data shows a steady increase in reporting in organizations with up to 499 employees. After peaking as at 3.7\% reporting for organizations with 100-499 staff, the percentage plummets to $0 \%$ as none of the 31 organizations with 500 or more staff reported any LGBTQ 
data. Hence, the reporting of LGBTQ deviates from the pattern of reporting gender and race/ethnicity data in the most prominent organizations.

\subsection{The Relationship between the Gender and Race of the CEO and the Reporting of Demographic Data}

The gender of most of the CEOs/presidents/executive directors (after this CEO) was unknown or undetermined (Table 7). Of the 6528 organizations for which this was the case, 77 or $1.2 \%$ revealed diversity data. Of the 5526 organizations for which the CEO's gender was known, $54.8 \%$ of the CEO's were male. One hundred and eighty-seven of those 3029 male-headed organizations reported diversity data. Notwithstanding, organizations with female CEOs were more likely to report diversity data. That is, 185 of the 2497 organizations with female CEOs divulged their diversity data.

Table 7. Gender and Race of the CEO and Variations in the Reporting of Diversity Data.

\begin{tabular}{cccccc}
\hline $\begin{array}{c}\text { Gender and Race } \\
\text { of CEO }\end{array}$ & $\begin{array}{c}\text { Number of } \\
\text { Organizations } \\
\text { Studied }\end{array}$ & $\begin{array}{c}\text { Number of } \\
\text { Organizations } \\
\text { Reporting Data }\end{array}$ & $\begin{array}{c}\text { Percent } \\
\text { Reporting } \\
\text { Gender }\end{array}$ & $\begin{array}{c}\text { Percent } \\
\text { Reporting } \\
\text { Race/Ethnicity }\end{array}$ & $\begin{array}{c}\text { Percent } \\
\text { Reporting } \\
\text { LGBTQ }\end{array}$ \\
\hline Gender of CEO: & & & & & \\
\hline $\begin{array}{c}\text { CEO's Gender } \\
\text { Unknown, }\end{array}$ & 6528 & 77 & 1.2 & 0.5 & 0.0 \\
\hline Male CEO & 3029 & 187 & 6.2 & 3.6 & 0.6 \\
\hline Female CEO & 2497 & 185 & 7.4 & 4.4 & 0.6 \\
\hline $\begin{array}{c}\text { Race/Ethnicity of } \\
\text { CEO }\end{array}$ & & & & & \\
\hline $\begin{array}{c}\text { CEO's Race } \\
\text { Unknown, } \\
\text { Undetermined }\end{array}$ & 6937 & 83 & 1.2 & 0.6 & 0.0 \\
\hline White CEO & 4753 & 327 & 6.9 & 3.8 & 0.6 \\
\hline Ethnic Minority CEO & 364 & 39 & 10.7 & 8.5 & 0.8 \\
\hline
\end{tabular}

Figure 4 indicates that while $6.2 \%$ of the organizations with male CEO's divulge gender diversity data, $7.4 \%$ of the institutions with female CEOs reveal this type of data. Similarly, male-headed organizations were less likely to reveal race/ethnicity data than female-headed institutions. Hence, $3.6 \%$ of the organizations with male CEOs and $4.4 \%$ of organizations with female CEOs divulged race/ethnicity data. There was no difference in the percentage of male-headed and female-headed environmental nonprofits that disclosed LGBTQ data; $0.6 \%$ of each type of institution divulged this type of data.

The race/ethnicity of the CEO has a more dramatic impact on the reporting of diversity data than the CEO's gender. We identified the race or ethnicity for 4753 White CEOs and 364 racial/ethnic minority CEOs (see Table 7). Of the CEOs for whom race/ethnicity was known, Whites constituted $92.9 \%$ of the subsample, while the remaining $7.1 \%$ of the CEOs were racial/ethnic minorities. Figure 7 indicates that racial/ethnic minority CEO's were more likely to reveal the three types of diversity data studied than White CEOs. Moreover, ethnic minority CEOs were twice as likely as White CEOs to reveal race/ethnicity data. That is, $3.8 \%$ of the White CEOs disclosed this type of data. In comparison, $8.5 \%$ of organizations with racial/ethnic minority CEOs revealed their race/ethnicity diversity data.

When it came to the release of gender diversity data, $10.7 \%$ of the organizations with racial/ethnic minority CEOs and $6.9 \%$ of those with White CEOs divulged their gender diversity data. Reporting of LGBTQ data was low across the board, but $0.6 \%$ of organizations with White CEOs and $0.8 \%$ of those with racial/ethnic minority CEOs reported this kind of diversity data.

How does the interaction between gender and race/ethnicity of the CEO influence the release of diversity data in environmental nonprofits? Analysis of the data from the 5526 organizations for which the gender of the CEO was known shows that organizations headed by White males were the least likely to disclose their diversity data while nonprofits with female, ethnic/racial minority CEOs were 
the most likely to reveal diversity data. As Table 8 shows, $6.5 \%$ of the organizations with White male CEOs reported diversity data, while $7.3 \%$ of the nonprofits with White female CEOs followed suit. In comparison, $9.2 \%$ of the institutions with ethnic minority male CEOs and $12.1 \%$ of those with female minority CEOs revealed their diversity data.

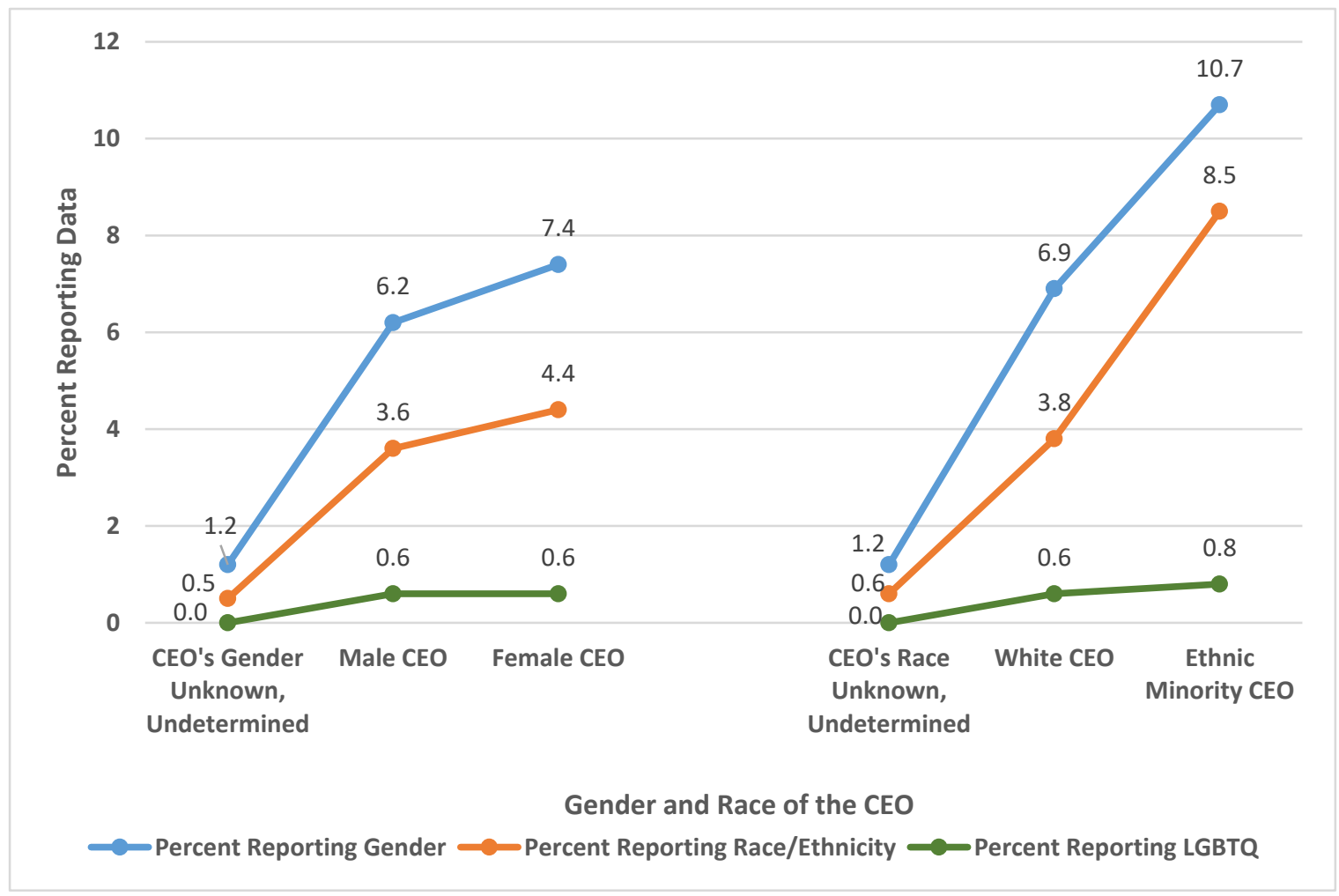

Figure 7. Gender and Race of the Chief Executive Officer an the Repoerting of Diversity Data.

Table 8. Interaction Between Gender and Race of the CEO and the Likelihood of Reporting of Diversity Data.

\begin{tabular}{ccccccc}
\hline & \multicolumn{2}{c}{ Organization has Male CEO } & \multicolumn{2}{c}{ Organization has Female CEO } \\
\hline Race of CEO & $\begin{array}{c}\text { Number of } \\
\text { Organizations } \\
\text { Studied }\end{array}$ & $\begin{array}{c}\text { Number of } \\
\text { Organizations } \\
\text { Reporting Data }\end{array}$ & $\begin{array}{c}\text { Percent } \\
\text { Reporting } \\
\text { Data }\end{array}$ & $\begin{array}{c}\text { Number of } \\
\text { Organizations } \\
\text { Studied }\end{array}$ & $\begin{array}{c}\text { Number of } \\
\text { Organizations } \\
\text { Reporting Data }\end{array}$ & $\begin{array}{c}\text { Percent } \\
\text { Reporting } \\
\text { Data }\end{array}$ \\
\hline $\begin{array}{c}\text { Unknown, } \\
\text { Undetermined }\end{array}$ & 257 & 2 & 0.8 & 155 & 4 & 2.6 \\
\hline White CEO & 2609 & 170 & 6.5 & 2143 & 157 & 7.3 \\
\hline $\begin{array}{c}\text { Ethnic Minority } \\
\text { CEO }\end{array}$ & 163 & 15 & 9.2 & 199 & 24 & 12.1 \\
\hline
\end{tabular}

\subsection{The Size of the Board and the Reporting of Demographic Data}

The size of the board has a less discernable impact on the reporting than the size of the organization's revenue, the number of employees, gender of the CEO, or race/ethnicity of the CEO. Nonetheless, the pattern discussed above holds-the larger the size of the board, the higher the likelihood of divulging diversity data. Hence, $5.2 \%$ of the organizations with fewer than ten board members reveal their diversity data. In comparison, $7.1 \%$ of those with $10-19$ board members and $8.5 \%$ of those with 20 or more board members release their diversity data (see Table 9 and Figure 8 ). 
Table 9. Size of the Board and Variations in the Reporting of Diversity Data.

\begin{tabular}{cccccc}
\hline Size of Board & $\begin{array}{c}\text { Number of } \\
\text { Organizations } \\
\text { Studied }\end{array}$ & $\begin{array}{c}\text { Number of } \\
\text { Organizations } \\
\text { Reporting }\end{array}$ & $\begin{array}{c}\text { Percent } \\
\text { Reporting } \\
\text { Gender }\end{array}$ & $\begin{array}{c}\text { Percent } \\
\text { Reporting } \\
\text { Race/Ethnicity }\end{array}$ & $\begin{array}{c}\text { Percent } \\
\text { Reporting } \\
\text { LGBTQ }\end{array}$ \\
\hline $\begin{array}{c}\text { Unknown, } \\
\text { Unspecified }\end{array}$ & 5448 & 30 & 0.6 & 0.3 & 0.0 \\
\hline $\begin{array}{c}\text { Less than } 10 \\
\text { Members }\end{array}$ & 3123 & 162 & 5.2 & 3.1 & 0.3 \\
\hline $\begin{array}{c}10-19 \text { Members } \\
\text { 20 or More } \\
\text { Members }\end{array}$ & 2815 & 200 & 7.1 & 4.0 & 0.6 \\
\hline
\end{tabular}

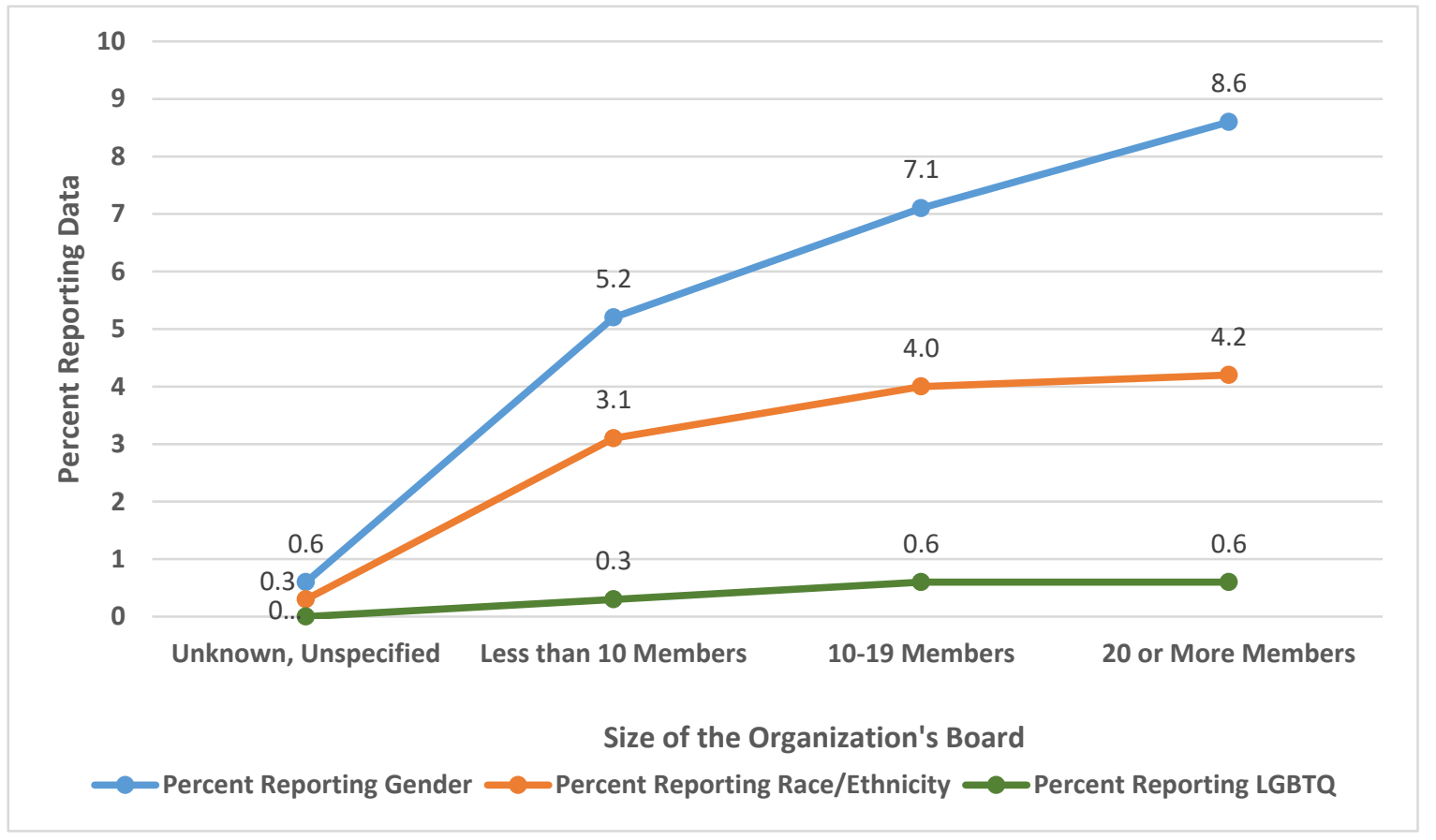

Figure 8. Size of Board and the Reporting of Diversity Data.

\subsection{Time Period GuideStar Profile Completed and the Discosure of Demographic Data}

An examination of the number of organizations that reported diversity data between 2014 and 2018 shows that the reporting of diversity data peaked in 2016, declined somewhat in 2017, and dropped significantly in 2018 (see Table 10 and Figure 9). So, the number of organizations reporting any diversity data has gone from 215 in 2016 to 174 in 2017 . Only 29 organizations reported any diversity data in 2018.

Table 10. GuideStar Profile and the Reporting of Diversity Data: 2014-2018.

\begin{tabular}{ccccccc}
\hline $\begin{array}{c}\text { Demographic } \\
\text { Data Reported }\end{array}$ & $\begin{array}{c}\text { Number } \\
\text { Reported in } \\
\mathbf{2 0 1 4}\end{array}$ & $\begin{array}{c}\text { Number } \\
\text { Reported in } \\
\mathbf{2 0 1 5}\end{array}$ & $\begin{array}{c}\text { Number } \\
\text { Reported in } \\
\mathbf{2 0 1 6}\end{array}$ & $\begin{array}{c}\text { Number } \\
\text { Reported in } \\
\mathbf{2 0 1 7}\end{array}$ & $\begin{array}{c}\text { Number } \\
\text { Reported in } \\
\mathbf{2 0 1 8}\end{array}$ & $\begin{array}{c}\text { Total Number of } \\
\text { Organizations } \\
\text { Reporting }\end{array}$ \\
\hline Gender & 6 & 23 & 215 & 174 & 29 & 447 \\
\hline Race/Ethnicity & 4 & 13 & 114 & 100 & 20 & 251 \\
\hline LGBTQ & 0 & 3 & 12 & 10 & 8 & 33 \\
\hline
\end{tabular}




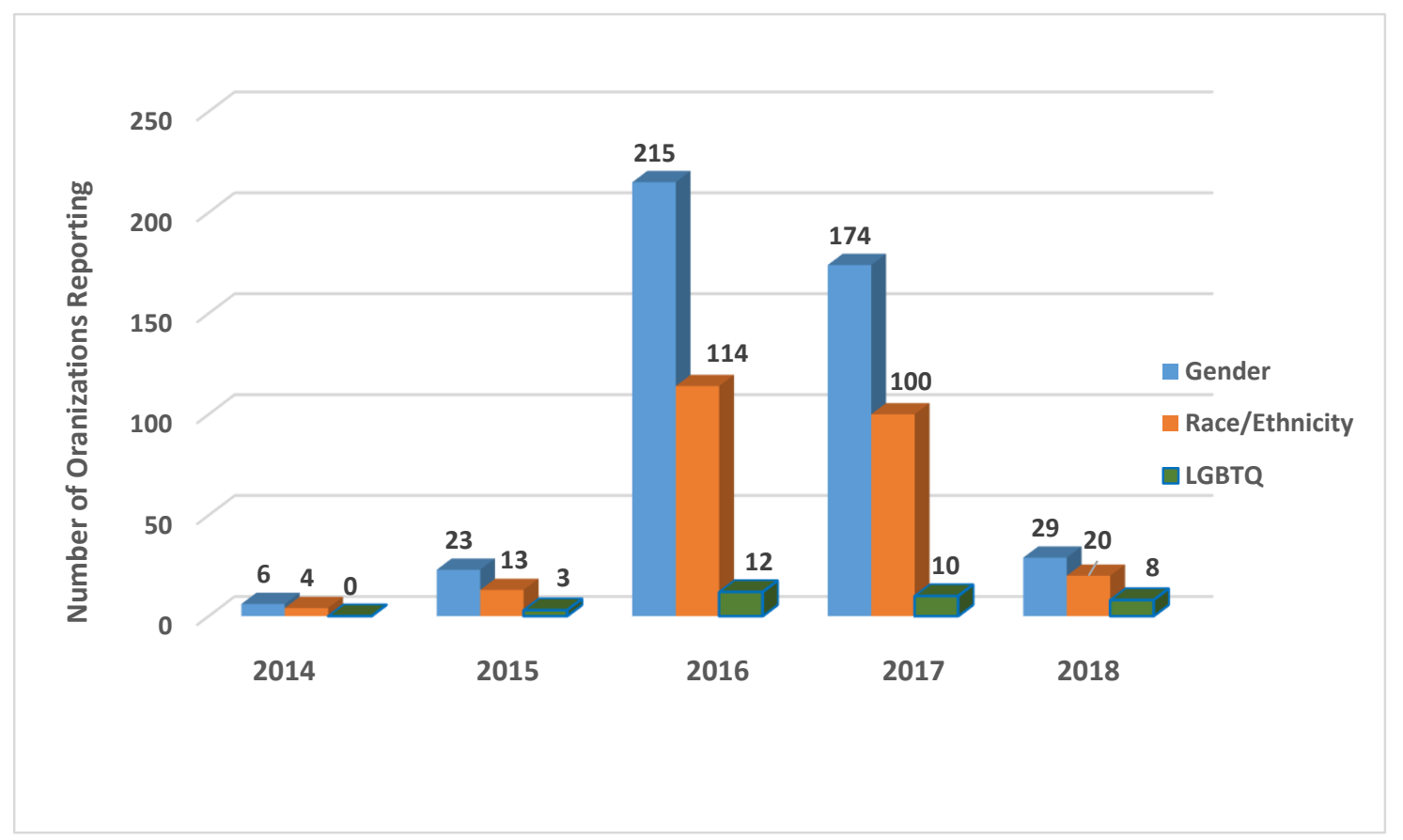

Figure 9. Number of Organizations Reporting Demographic Data from 2014-2018.

\section{Discussion and Implications}

Thus far, the campaign to increase transparency and release environmental diversity data has yielded modest results. It is worth noting that not all environmental sectors shy away from collecting and publishing diversity data. For instance, federal environmental agencies have been doing so for decades. As a result, the public can find information on a variety of demographic factors in agencies and bureaus such the Department of the Interior, the National Park Service, the Bureau of Land Management, the U.S. Department of Agriculture, the U.S. Forest Service, and the National Oceanic and Atmospheric Administration through websites like the Partnership for Public Service [43].

The tepid reporting of diversity data in environmental nonprofits is in line with research that finds that some corporations do not emphasize diversity and pay scant attention to it [57,58]. However, some scholars report that, increasingly, corporations view diversity as an essential element of their business operations. Corporations are also revealing their diversity statistics to the public $[23,59,60]$. This dimension of social responsibility and social sustainability has not caught on fully in environmental circles yet. Even after a campaign to collect and share diversity data publicly, only about 1 in every 25 environmental nonprofits disclose their diversity data on GuideStar.

This study helps us to understand some important factors about the organizations that do disclose their diversity data. Such information can be used to help to develop strategies that will facilitate more widespread disclosure of diversity data in the future. The study finds that the highest rate of reporting of diversity data occur in organizations is located in the nation's capital, the remainder of the Mid-Atlantic region, as well as in the Pacific region. Not only does this correspond to areas with the largest concentration of environmental organizations, but it also corresponds to the parts of the country in which large numbers of diversity programs are operating [56]. Diversity programming helps to keep the issue of reporting and transparency in the spotlight. It also facilitates collaboration between organizations working on diversity, equity, and inclusion activities and initiatives.

The research also identifies parts of the country with little or no reporting of diversity data that has been hitherto unknown to diversity advocates. Lack of reporting is most evident in the South as well as the Plains states. There was lackluster reporting in rural areas too. The study found that states in which there was no reporting of diversity data were also locales in which there were little to no diversity programming [56]. 
The study supports the findings of past research that argues that gender is positively related to the disclosure of social responsibility data $[40,42,43]$. Our study adds new information to this line of inquiry. An intersectional analysis of the impacts of the CEOs race and gender on reporting shows that these two variables interact in ways that affect the levels of reporting in profound ways. The data show that organizations with White male CEOs are the least likely to reveal diversity data. This is followed by organizations with White female CEOs and racial/ethnic minority male CEOs. The organizations that are most likely to reveal their diversity data are those headed by racial/ethnic minority female CEOs. This finding is worth interrogating further. Though corporate studies [61-63] have found gender to be related to the disclosure of diversity data, such studies have not examined how race and gender intersect to impact rates of reporting.

The size of the organization, as indicated by revenues and number of employees, is positively associated with an increased likelihood of divulging diversity data. The larger the revenues and the greater the number of employees, the more likely it is that the organization reveals its diversity data. The results lend some credence to the efforts thus far to focus attention on getting the largest enviros to reveal their diversity data. Efforts have also focused on tracking the extent to which the 40 largest organizations divulge such data [52,54]. However, the underlying logic of this strategy presumes that if the most prominent environmental nonprofits reveal their diversity data, there will be a cascading effect, and most of the other organizations will follow suit.

Our study suggests that there are limits to this strategy. We found a strong relationship between organizational revenues and the propensity to release diversity data. While less than $4 \%$ of the entire sample divulged demographic data, $26 \%$ of the 140 organizations with annual revenues that exceed $\$ 20$ million shared their diversity data publicly. An assessment of the 40 organizations with the largest revenues show that $42.5 \%$ of these organizations have revealed their diversity data (the annual revenues of these organizations exceed $\$ 60,000,000)$. Hence, focusing only on the top 40 or so environmental nonprofits can give a distorted image of impact as the rates of reporting are much higher among the largest organizations than they are in smaller ones.

Our study points to the need to focus on medium-sized and small environmental organizations as well. The number of smaller nonprofits that have revealed their diversity data thus far is limited. The study also demonstrates that efforts to increase the reporting of diversity data must be informed by the spatial patterns evident in reporting and non-reporting. Not only does this study show areas within each region with high and low reporting, such variations exist within all the states and territories. This study indicates that larger, much more nuanced and multi-pronged campaigns for greater transparency are needed. It also implies that much greater resources are needed to enhance the effectiveness of such efforts.

Campaigns to encourage the collection of diversity data in enviros and the public release of such data have not framed these activities as part of the social responsibility and social sustainability mission of the organizations. Neither has the research on environmental, institutional diversity. This paper argues that diversity data collection and disclosure are vital and that environmental organizations should embrace these activities as essential elements of their mission. But, as earlier discussions indicate, some environmental leaders have expressed discomfort with the idea that social issues belong in their organizational mission. Some have also questioned outright the wisdom of incorporating diversity issues into their institutional framework [4,8,13-15,22].

However, the Green 2.0 campaign to get increased reporting of diversity data revealed that several high-profile leaders of environmental organizations are willing and ready to divulge their diversity data and urge others to do likewise. The heads of several major environmental grantmaking foundations also supported the initiative $[34,36,37,54,55]$. This study makes it clear that diversity advocates still have to grapple with this question: What steps can be taken to effectively broaden the efforts to collect diversity data and publicly disclose them?

The data presented above suggest that interest in reporting diversity data is waning. The decline is worth investigating to find out why the number of organizations that are reporting diversity data has 
been declining since 2016. This study was not designed to answer the question-why is there a decline in the number of organizations that reveal their diversity data? There are several reasons why this could be the case. Such reasons could include the following: Resistance to the idea that environmental nonprofits should collect and report diversity data; shifting political climate since the 2016 election to one that is less tolerant of diversity; organizations do not actually collect diversity data so have nothing to report; organizations have no staff or too few staff to collect and track such data; institutions have not heard of the GuideStar project and diversity reporting system; or institutions do not update their GuideStar profiles.

Our findings highlight the need to conduct regular, comprehensive analyses to identify which organizations do and do not collect and reveal diversity data. Such studies should also examine why organizations report such data and what prevents others from doing so. Further research by this team will explore why environmental nonprofits do not reveal diversity data.

\section{Limitations of the Study}

Though the study contained an extensive sample of environmental organizations, there were limitations to it. The analysis in this paper is limited to the exploration of bivariate relationships and a few probes into interaction effects. The paper does not explore multivariate analysis. Adding multivariate analyses to a paper of this sort would add unnecessary complexity to the paper and quite possibly overwhelm the reader.

As mentioned in the previous section, the paper examined what types of organizations revealed their diversity data, but this study could not examine the reasons why organizations refrained from reporting such data. Data presented above came from sources that did not have information on why organizations chose to reveal their diversity data or not. We are aware of the fact that revealing diversity data might not translate into extensive or deep engagement with diversity issues inside an institution. Despite this limitation, we feel that the act of publicly revealing demographic information is an indicator of interest in and action on diversity that is worth tracking and assessing.

The paper examined how the size of the board and staff influence the reporting of diversity data. However, it did not examine how the gender or racial/ethnicity composition of the board is related to the disclosure of diversity data. Since past research suggest that these factors are significant, these aspects of diversity reporting should be examined in the future.

The design of this study limited the analysis of disclosure of diversity data to information on tax forms and the GuideStar platform. However, organizations could release diversity data elsewhere or on other platforms. Hence, future studies should explore whether organizations reveal diversity data publicly in other spaces or forums besides GuideStar, how many are doing so, and where else are these data disclosed.

\section{Conclusions}

Environmental organizations have pushed corporations to be socially responsible for decades. It is time for environmental nonprofits to practice what they preach and pay more attention to diversity, equity, and inclusion as these socially responsible practices that should be a part of every environmental organization's mission. The long-term sustainability of environmental organizations depends on the creation of workplaces that are based on and practice these principles.

Environmental organizations must reveal data about their demographic characteristics on their websites or platforms such as GuideStar. Such actions send a signal that an institution is engaging in diversity conversations and initiatives at some level. It is a signifier of inclusivity or the awareness of the need to be more inclusive. It shows that organizations are willing to name a challenge that has bedeviled many in the environmental sector for the better part of two centuries. It suggests that organizations are eager to start the process and embark on the journey of enhancing institutional diversity, equity, and inclusion in their place of work. 
More comprehensive strategies for promoting the collection and reporting of data are needed. Organizations may be encouraged to reveal their data on multiple platforms. Additionally, environmental grantmaking foundations have supported the idea of collecting and reporting diversity data publicly. Foundations could play a role in this initiative by collecting and disclosing their own data. They can also encourage their environmental grantees to collect and disclose their diversity data as well.

Author Contributions: D.E.T. obtained funding for, conceptualized, and directed the project. D.E.T. also collected data as well as supervised data collection, analyzed the data, wrote the draft, reviewed and edited the paper, and made revisions. S.P. collected data and helped with the supervision of data collection. S.P. also helped to write the methodology section of the paper and the creation of maps. E.M. collected data and created the maps. E.M. also helped to write the methodology section of the paper.

Funding: This research was funded by The JPB Foundation, the C.S. Mott Foundation, and the Nathan Cummings Foundation.

Conflicts of Interest: The authors declare no conflict of interest.

\section{Appendix A}

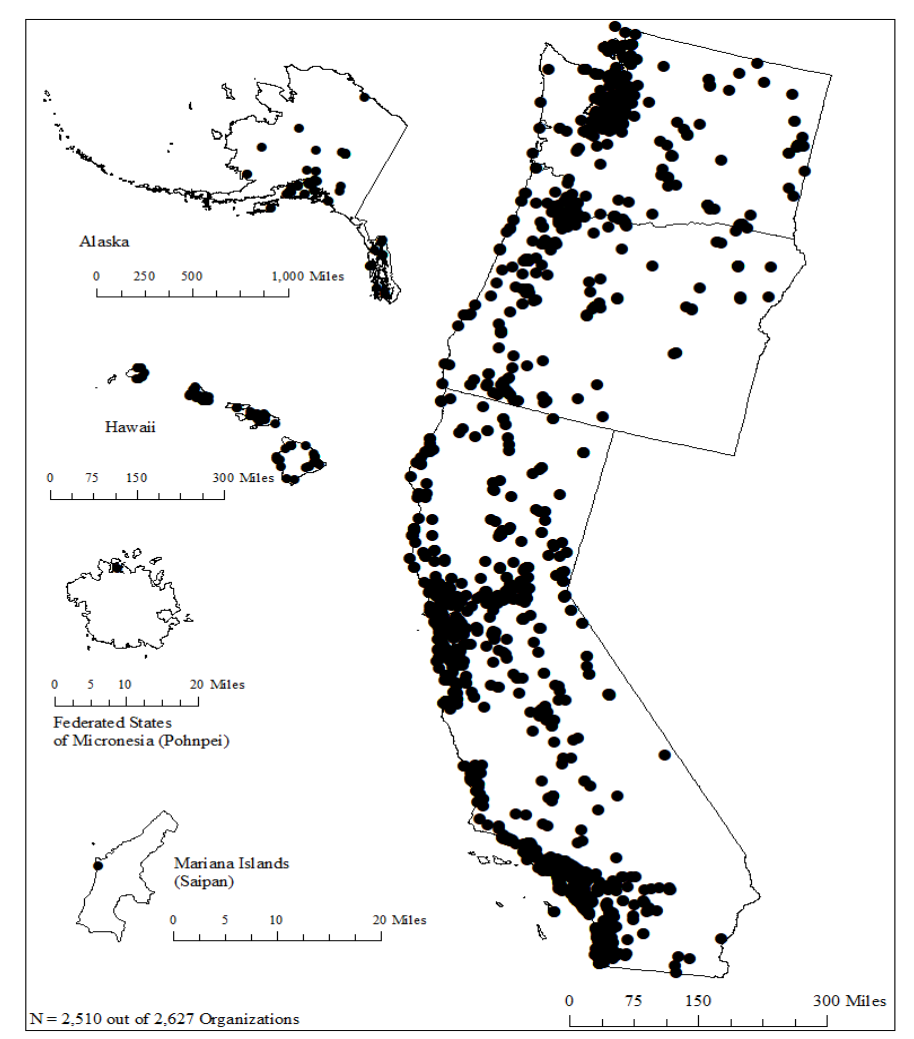

Figure A1. Pacific Region: Organizations that did not Report Diversity Data. 


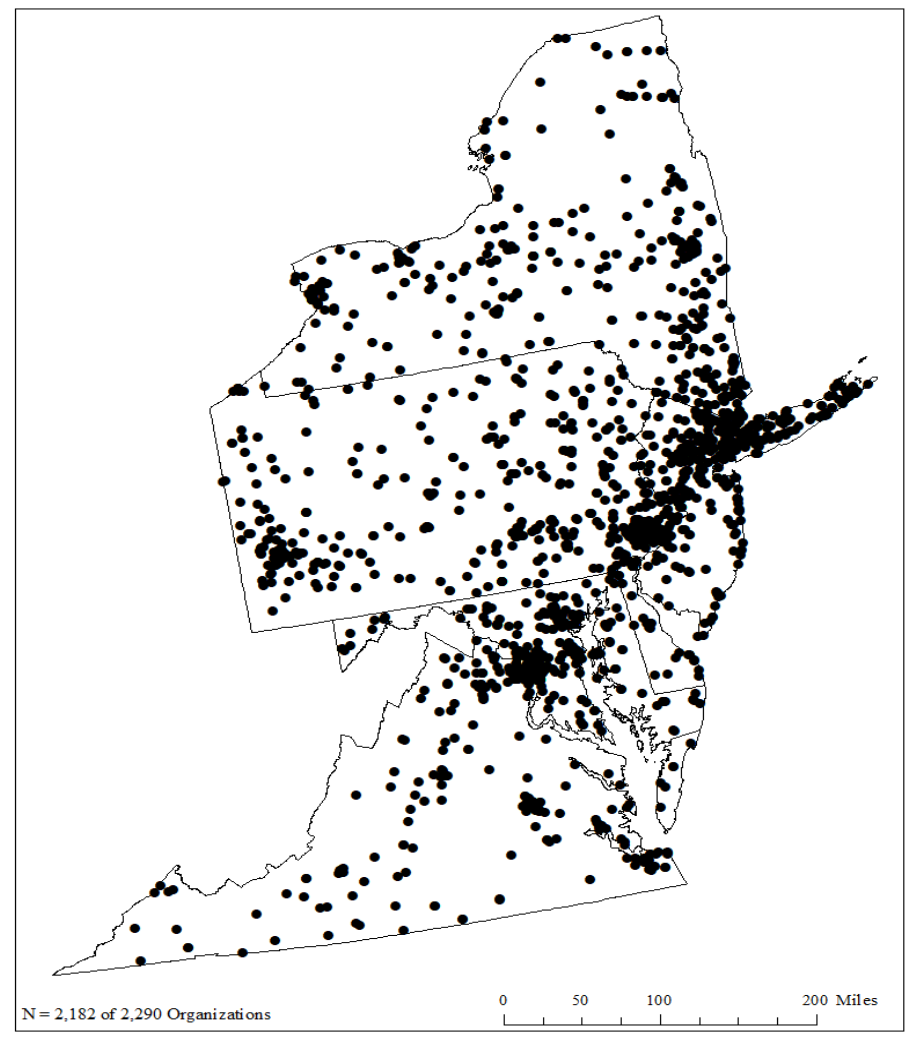

Figure A2. Mid-Atlantic Region: Organizations that did not Report Diversity Data.

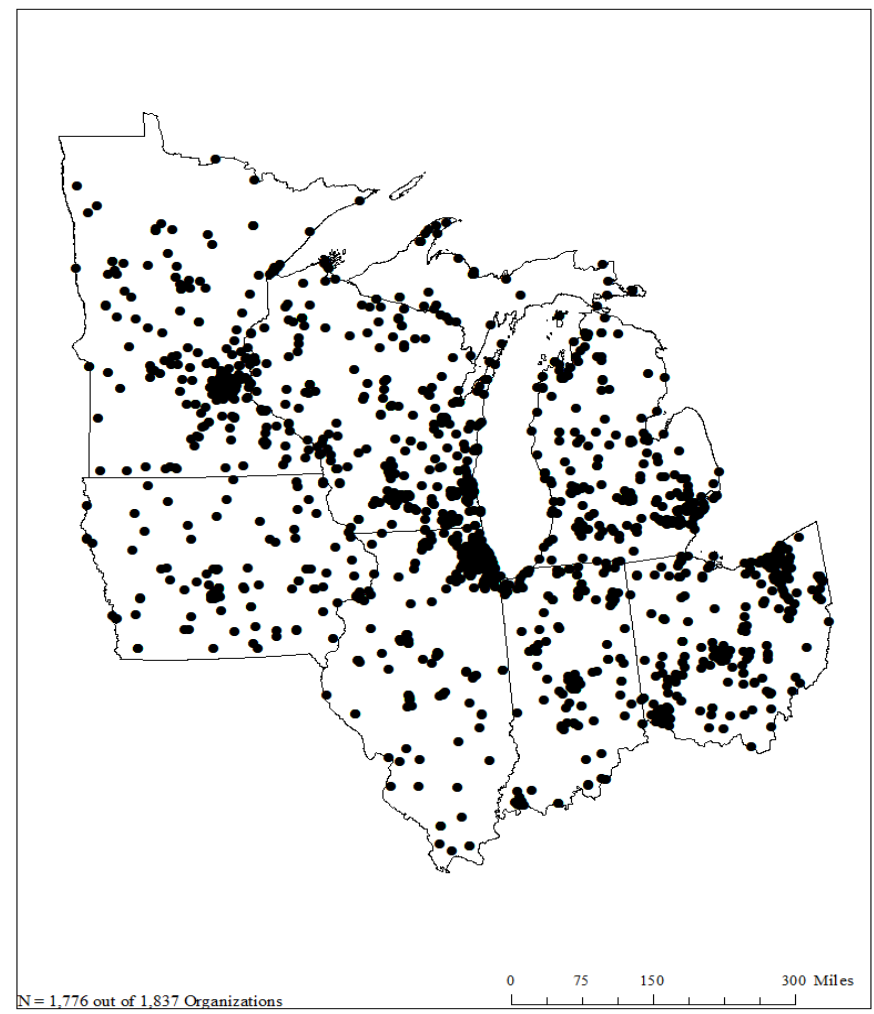

Figure A3. Midwest Region: Organizations that did not Report Diversity Data. 


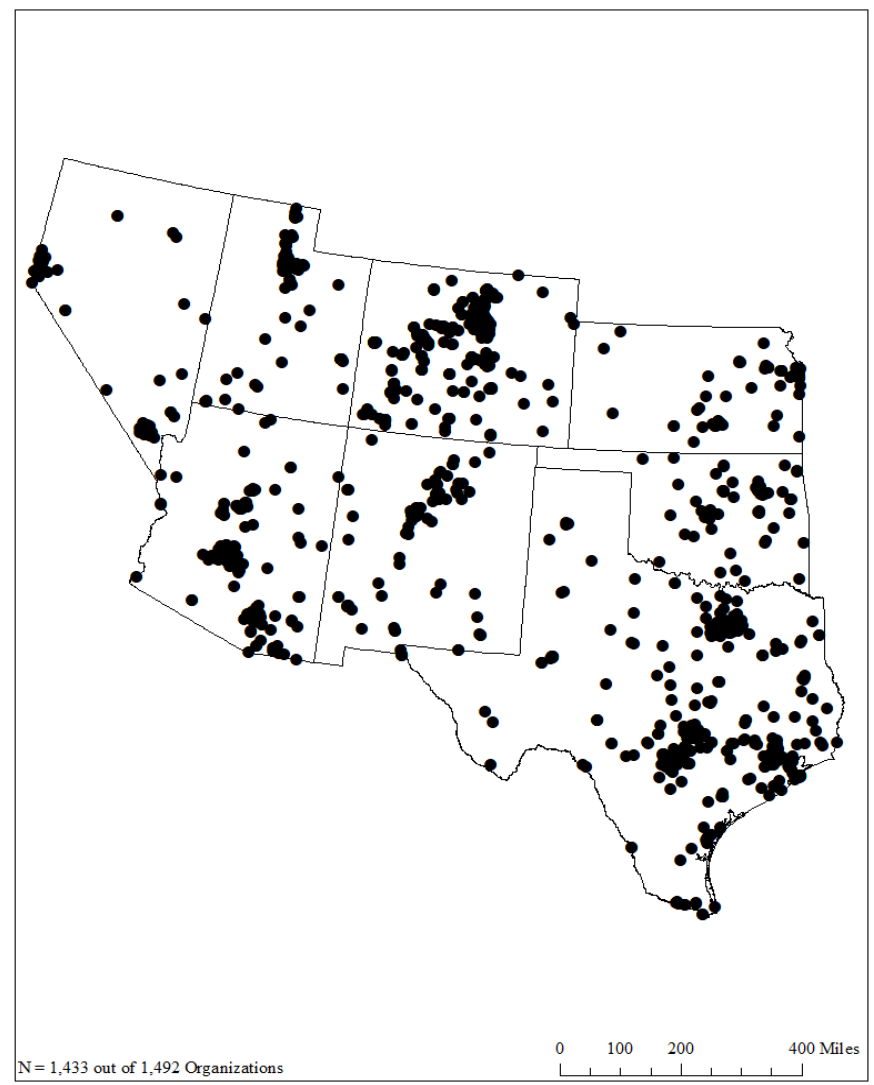

Figure A4. Southwest Region: Organizations that did not Report Diversity Data.

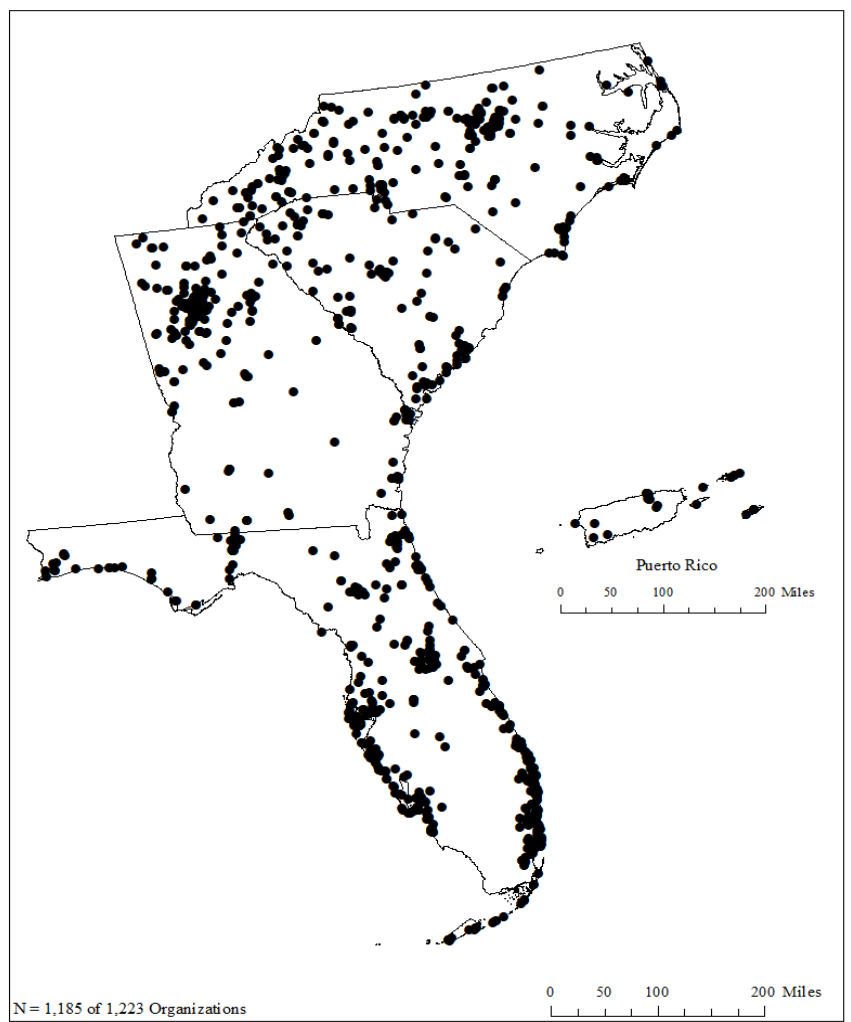

Figure A5. Southeast Region: Organizations that did not Report Diversity Data. 


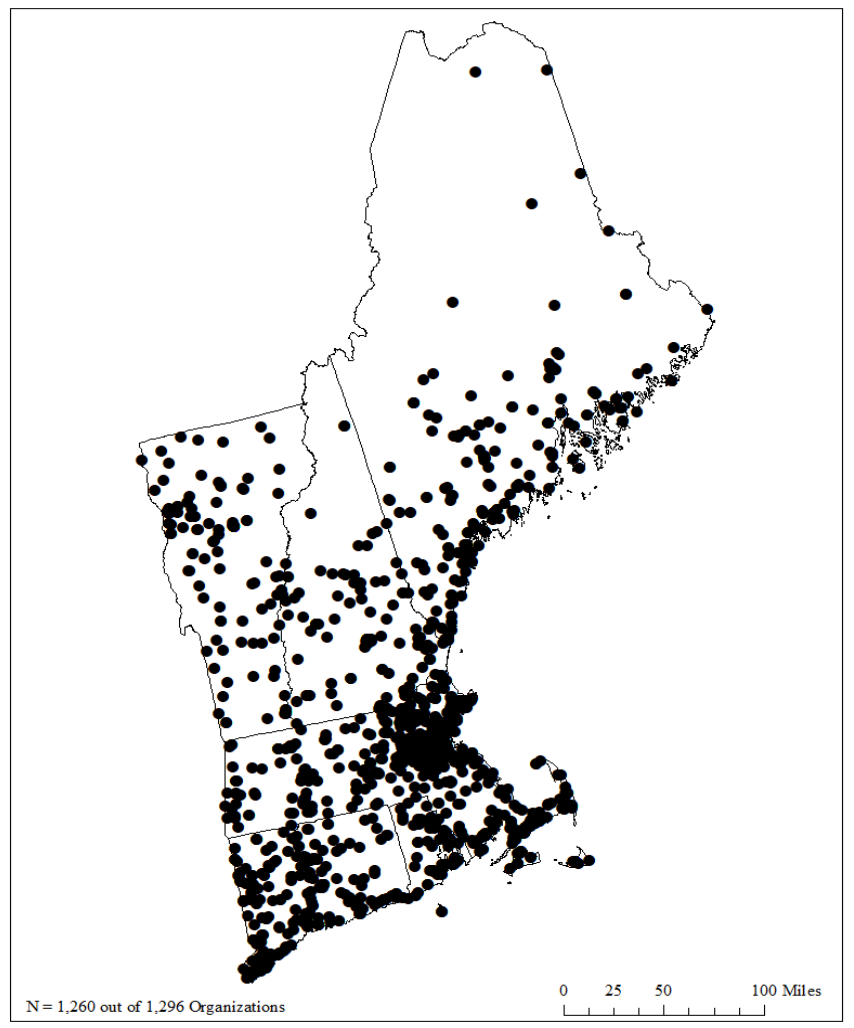

Figure A6. New England Region: Organizations that did not Report Diversity Data.

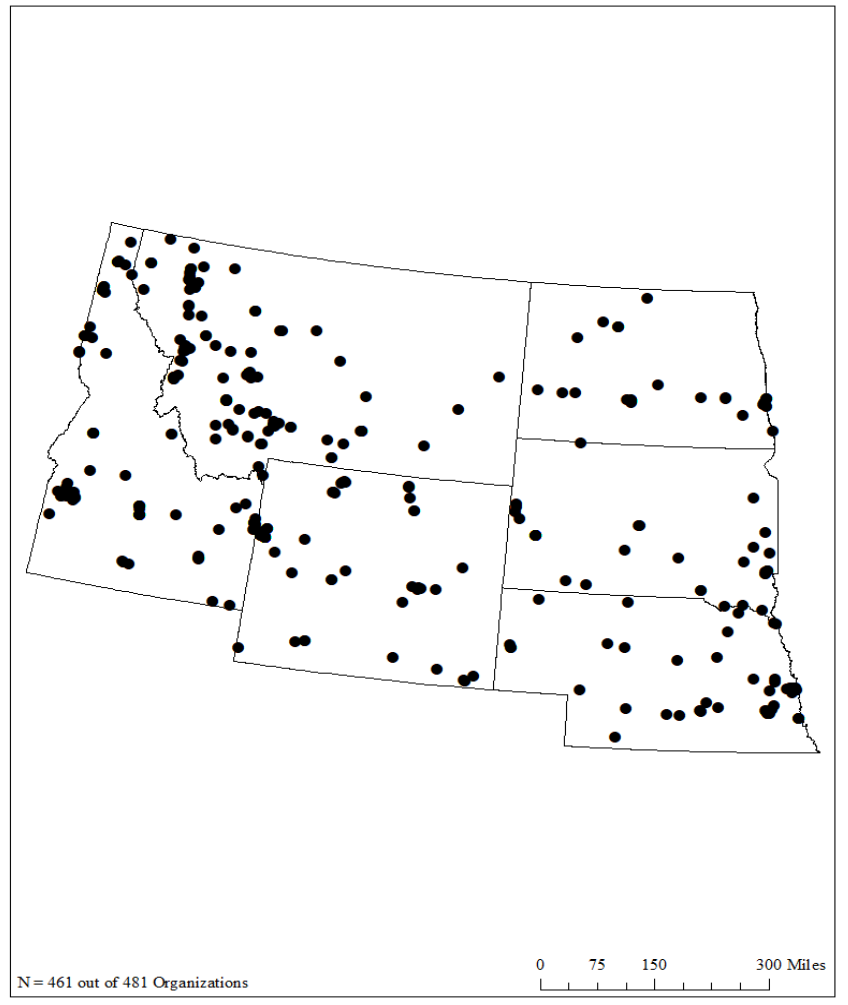

Figure A7. Plains-Mountain Region: Organizations that did not Report Diversity Data. 


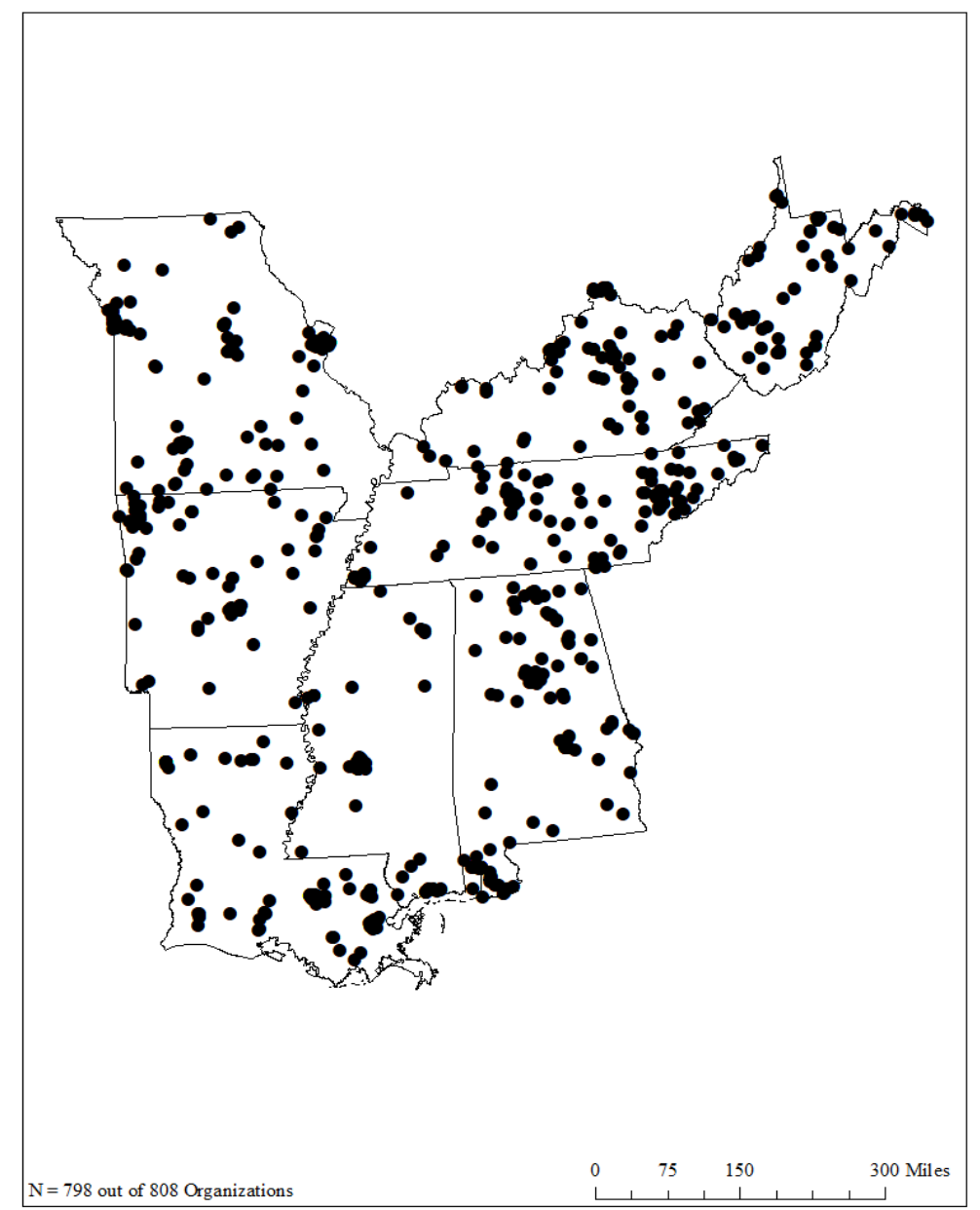

Figure A8. South Region: Organizations that did not Report Diversity Data. 


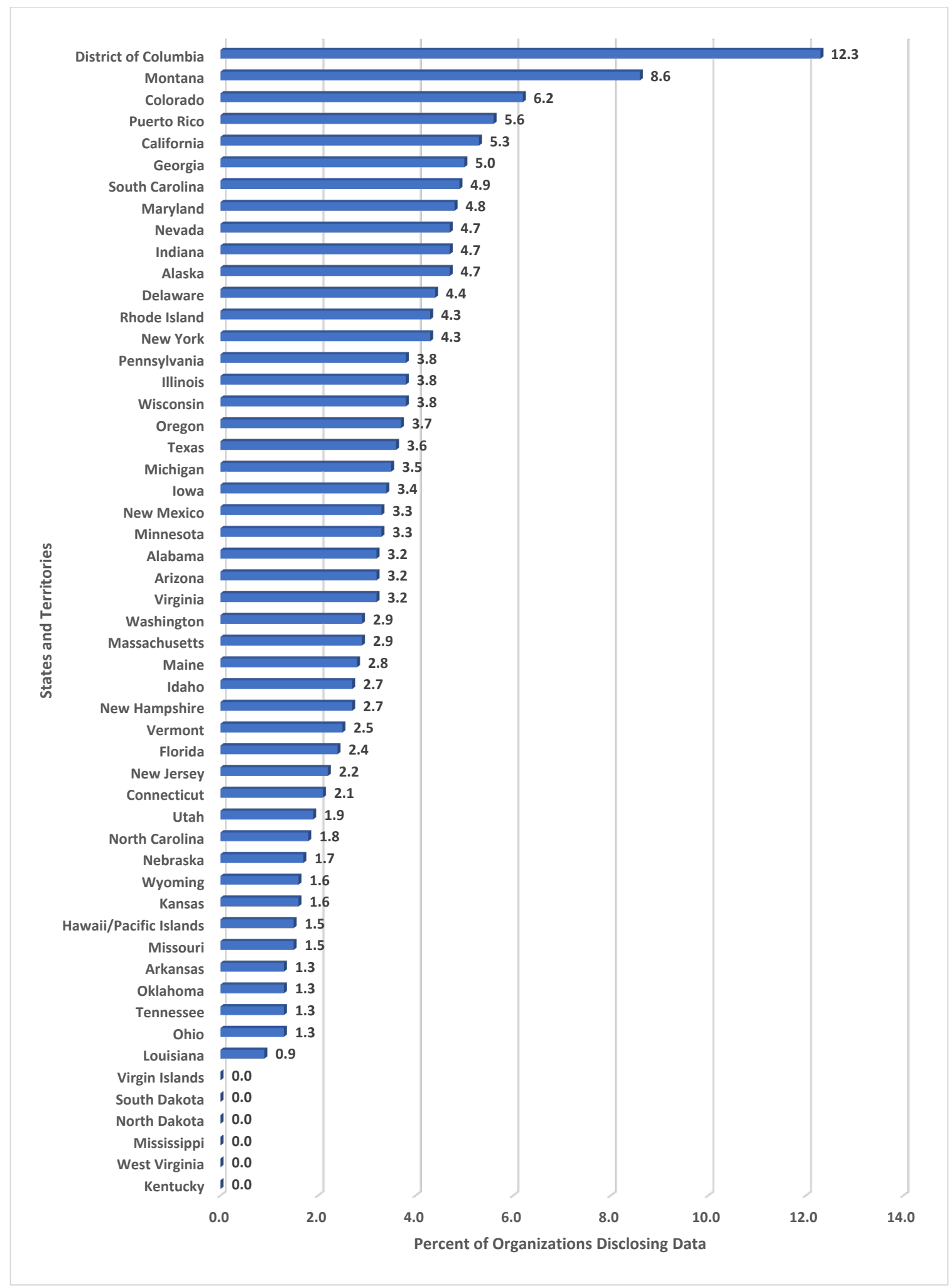

Figure A9. Percent of Environmental Nonprofits in Each State or Territory that Report Staff or Board Diversity Data. 


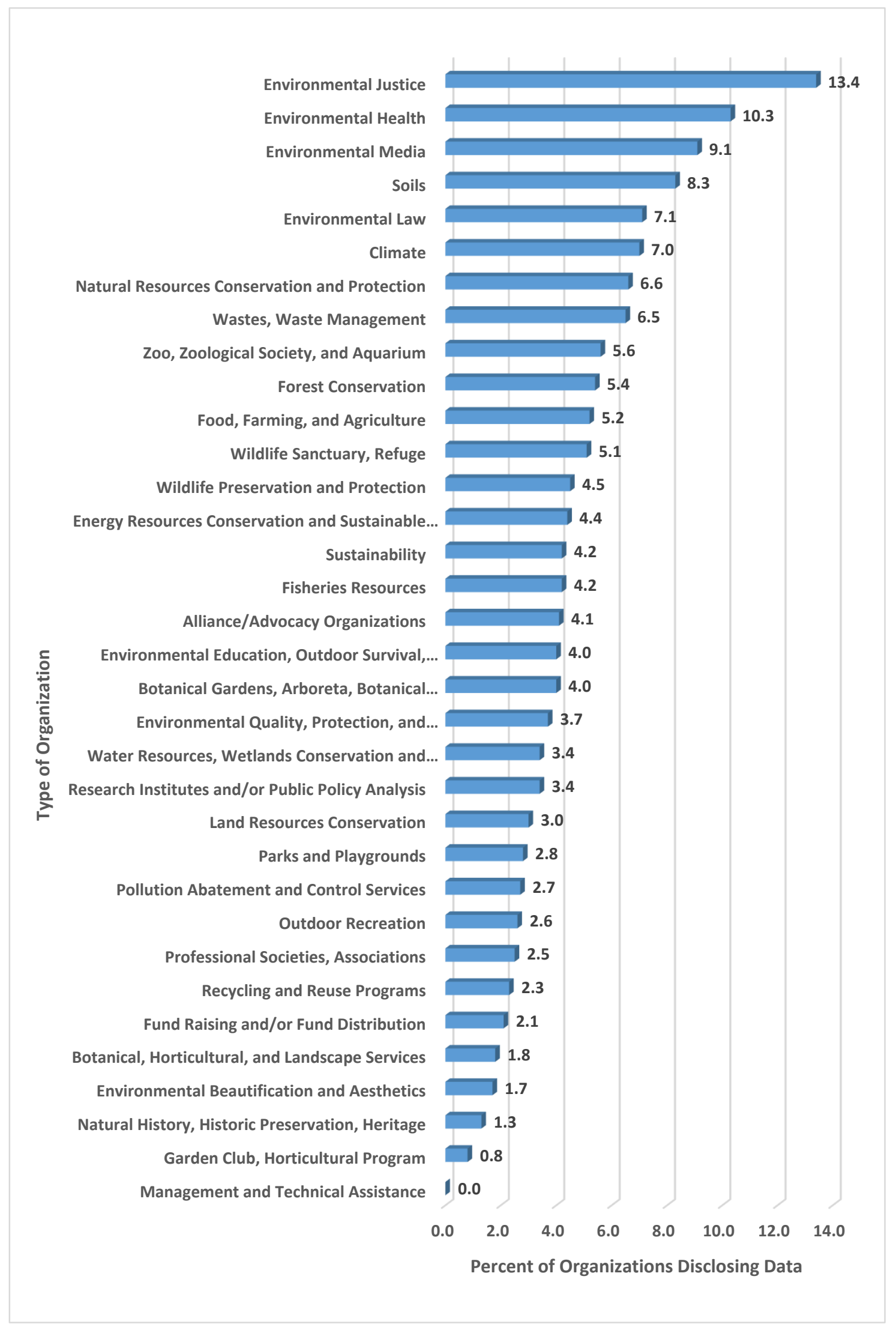

Figure A10. Organizational Type and Percent of Environmental Nonprofits that Report Staff and Diversity Data. 
Table A1. Reporting of Diversity Data in States and Territories.

\begin{tabular}{|c|c|c|c|c|c|}
\hline $\begin{array}{l}\text { State or } \\
\text { Territory }\end{array}$ & $\begin{array}{c}\text { Number of } \\
\text { Organizations } \\
\text { Studied }\end{array}$ & $\begin{array}{c}\text { Number of } \\
\text { Organizations } \\
\text { Reporting Data }\end{array}$ & $\begin{array}{c}\text { Percent } \\
\text { Reporting } \\
\text { Gender }\end{array}$ & $\begin{array}{c}\text { Percent } \\
\text { Reporting } \\
\text { Race/Ethnicity }\end{array}$ & $\begin{array}{c}\text { Percent } \\
\text { Reporting } \\
\text { LGBTQ }\end{array}$ \\
\hline California & 1,543 & 82 & 5.3 & 3.4 & 0.4 \\
\hline New York & 700 & 30 & 4.3 & 2.9 & 0.3 \\
\hline $\begin{array}{l}\text { District of } \\
\text { Columbia }\end{array}$ & 236 & 29 & 12.3 & 9.7 & 3.4 \\
\hline Colorado & 404 & 25 & 6.2 & 3.0 & 0.2 \\
\hline Pennsylvania & 520 & 20 & 3.8 & 2.3 & 0.0 \\
\hline Massachusetts & 550 & 16 & 2.9 & 1.6 & 0.2 \\
\hline Texas & 448 & 16 & 3.6 & 2.0 & 0.0 \\
\hline Oregon & 405 & 15 & 3.7 & 2.2 & 0.5 \\
\hline Montana & 175 & 15 & 8.6 & 4.0 & 0.0 \\
\hline Wisconsin & 368 & 14 & 3.8 & 1.9 & 0.3 \\
\hline Florida & 535 & 13 & 2.4 & 0.7 & 0.0 \\
\hline Washington & 416 & 12 & 2.9 & 1.4 & 0.0 \\
\hline Maryland & 251 & 12 & 4.8 & 3.2 & 0.8 \\
\hline Georgia & 241 & 12 & 5.0 & 2.9 & 0.0 \\
\hline Michigan & 316 & 11 & 3.5 & 1.6 & 0.3 \\
\hline Illinois & 287 & 11 & 3.8 & 2.8 & 0.3 \\
\hline Virginia & 313 & 10 & 3.2 & 1.6 & 0.3 \\
\hline Minnesota & 270 & 9 & 3.3 & 1.1 & 0.4 \\
\hline Indiana & 172 & 8 & 4.7 & 2.9 & 0.0 \\
\hline South Carolina & 143 & 7 & 4.9 & 2.1 & 0.0 \\
\hline Maine & 211 & 6 & 2.8 & 1.4 & 0.0 \\
\hline Arizona & 186 & 6 & 3.2 & 1.6 & 0.5 \\
\hline Alaska & 129 & 6 & 4.7 & 2.3 & 0.0 \\
\hline North Carolina & 277 & 5 & 1.8 & 0.7 & 0.4 \\
\hline Connecticut & 236 & 5 & 2.1 & 0.4 & 0.0 \\
\hline New Jersey & 225 & 5 & 2.2 & 1.3 & 0.0 \\
\hline Ohio & 306 & 4 & 1.3 & 0.7 & 0.0 \\
\hline Alabama & 124 & 4 & 3.2 & 1.6 & 0.0 \\
\hline New Mexico & 120 & 4 & 3.3 & 3.3 & 0.0 \\
\hline Iowa & 118 & 4 & 3.4 & 3.4 & 0.8 \\
\hline Nevada & 86 & 4 & 4.7 & 1.2 & 1.2 \\
\hline Vermont & 120 & 3 & 2.5 & 0.8 & 0.0 \\
\hline $\begin{array}{c}\text { New } \\
\text { Hampshire }\end{array}$ & 110 & 3 & 2.7 & 0.9 & 0.9 \\
\hline Idaho & 110 & 3 & 2.7 & 1.8 & 0.0 \\
\hline Rhode Island & 69 & 3 & 4.3 & 0.0 & 0.0 \\
\hline Tennessee & 155 & 2 & 1.3 & 0.6 & 0.0 \\
\hline Missouri & 136 & 2 & 1.5 & 0.7 & 0.0 \\
\hline Utah & 106 & 2 & 1.9 & 0.9 & 0.0 \\
\hline Delaware & 45 & 2 & 4.4 & 0.0 & 0.0 \\
\hline
\end{tabular}


Table A1. Cont.

\begin{tabular}{cccccc}
\hline $\begin{array}{c}\text { State or } \\
\text { Territory }\end{array}$ & $\begin{array}{c}\text { Number of } \\
\text { Organizations } \\
\text { Studied }\end{array}$ & $\begin{array}{c}\text { Number of } \\
\text { Organizations } \\
\text { Reporting Data }\end{array}$ & $\begin{array}{c}\text { Percent } \\
\text { Reporting } \\
\text { Gender }\end{array}$ & $\begin{array}{c}\text { Percent } \\
\text { Reporting } \\
\text { Race/Ethnicity }\end{array}$ & $\begin{array}{c}\text { Percent } \\
\text { Reporting } \\
\text { LGBTQ }\end{array}$ \\
\hline $\begin{array}{c}\text { Hawaii/Pacific } \\
\text { Islands }\end{array}$ & 134 & 1 & 1.5 & 0.8 & 0.0 \\
\hline Louisiana & 114 & 1 & 0.9 & 0.9 & 0.9 \\
\hline Oklahoma & 78 & 1 & 1.3 & 1.3 & 0.0 \\
\hline Arkansas & 76 & 1 & 1.3 & 0.0 & 0.0 \\
\hline Kansas & 64 & 1 & 1.6 & 0.0 & 0.0 \\
\hline Wyoming & 63 & 1 & 1.6 & 1.6 & 0.0 \\
\hline Nebraska & 58 & 1 & 1.7 & 0.0 & 0.0 \\
\hline Puerto Rico & 18 & 0 & 5.6 & 0.0 & 0.0 \\
\hline Kentucky & 93 & 0 & 0.0 & 0.0 & 0.0 \\
\hline West Virginia & 63 & 0 & 0.0 & 0.0 & 0.0 \\
\hline Mississippi & 47 & 0 & 0.0 & 0.0 & 0.0 \\
\hline North Dakota & 39 & 0 & 0.0 & 0.0 & 0.0 \\
\hline South Dakota & 36 & 0 & 0.0 & 0.0 & 0.0 \\
\hline Virgin Islands & 9 & 0.0 & 0.0 & 0.0 \\
\hline
\end{tabular}

Table A2. Organizational Type and Variations in the Reporting of Diversity Data.

\begin{tabular}{|c|c|c|c|c|c|}
\hline Organizational Type & $\begin{array}{c}\text { Number of } \\
\text { Organizations } \\
\text { Studied }\end{array}$ & $\begin{array}{c}\text { Number of } \\
\text { Organizations } \\
\text { Reporting Data } \\
\end{array}$ & $\begin{array}{l}\text { Percent } \\
\text { Reporting } \\
\text { Gender }\end{array}$ & $\begin{array}{c}\text { Percent } \\
\text { Reporting } \\
\text { Race/Ethnicity }\end{array}$ & $\begin{array}{c}\text { Percent } \\
\text { Reporting } \\
\text { LGBTQ }\end{array}$ \\
\hline $\begin{array}{c}\text { Water Resources, } \\
\text { Wetlands Conservation } \\
\text { and Management }\end{array}$ & 2040 & 69 & 3.4 & 1.8 & 0.3 \\
\hline $\begin{array}{l}\text { Natural Resources } \\
\text { Conservation and } \\
\text { Protection }\end{array}$ & 788 & 52 & 6.6 & 4.8 & 0.8 \\
\hline $\begin{array}{l}\text { Land Resources } \\
\text { Conservation }\end{array}$ & 1618 & 48 & 3.0 & 1.1 & 0.2 \\
\hline $\begin{array}{c}\text { Energy Resources } \\
\text { Conservation and } \\
\text { Sustainable } \\
\text { Development }\end{array}$ & 496 & 22 & 4.4 & 2.4 & 0.2 \\
\hline Forest Conservation & 409 & 22 & 5.4 & 3.2 & 0.2 \\
\hline Environmental Justice & 157 & 21 & 13.4 & 10.8 & 1.9 \\
\hline $\begin{array}{c}\text { Environmental } \\
\text { Education, Outdoor } \\
\text { Survival, Nature Centers }\end{array}$ & 521 & 21 & 4.0 & 2.9 & 0.4 \\
\hline $\begin{array}{l}\text { Environmental Quality, } \\
\text { Protection, and } \\
\text { Beautification }\end{array}$ & 483 & 18 & 3.7 & 1.9 & 0.6 \\
\hline Sustainability & 357 & 15 & 4.2 & 2.8 & 0.3 \\
\hline $\begin{array}{c}\text { Botanical Gardens, } \\
\text { Arboreta, Botanical } \\
\text { Organizations }\end{array}$ & 348 & 14 & 4.0 & 2.3 & 0.0 \\
\hline $\begin{array}{l}\text { Food, Farming, and } \\
\text { Agriculture }\end{array}$ & 270 & 14 & 5.2 & 2.6 & 0.4 \\
\hline
\end{tabular}


Table A2. Cont.

\begin{tabular}{|c|c|c|c|c|c|}
\hline Organizational Type & $\begin{array}{c}\text { Number of } \\
\text { Organizations } \\
\text { Studied }\end{array}$ & $\begin{array}{c}\text { Number of } \\
\text { Organizations } \\
\text { Reporting Data }\end{array}$ & $\begin{array}{l}\text { Percent } \\
\text { Reporting } \\
\text { Gender }\end{array}$ & $\begin{array}{c}\text { Percent } \\
\text { Reporting } \\
\text { Race/Ethnicity }\end{array}$ & $\begin{array}{c}\text { Percent } \\
\text { Reporting } \\
\text { LGBTQ }\end{array}$ \\
\hline $\begin{array}{c}\text { Environmental } \\
\text { Beautification and } \\
\text { Aesthetics }\end{array}$ & 699 & 12 & 1.7 & 0.6 & 0.0 \\
\hline $\begin{array}{l}\text { Research Institutes } \\
\text { and/or Public Policy } \\
\text { Analysis }\end{array}$ & 351 & 12 & 3.4 & 2.6 & 0.9 \\
\hline $\begin{array}{l}\text { Zoo, Zoological Society, } \\
\text { and Aquarium }\end{array}$ & 213 & 12 & 5.6 & 2.3 & 0.5 \\
\hline Parks and Playgrounds & 394 & 11 & 2.8 & 1.0 & 0.0 \\
\hline $\begin{array}{l}\text { Wildlife Preservation } \\
\text { and Protection }\end{array}$ & 245 & 11 & 4.5 & 1.6 & 0.0 \\
\hline Climate & 114 & 8 & 7.0 & 2.1 & 0.0 \\
\hline $\begin{array}{l}\text { Professional Societies, } \\
\text { Associations }\end{array}$ & 277 & 7 & 2.5 & 1.4 & 0.0 \\
\hline Outdoor Recreation & 266 & 7 & 2.6 & 1.1 & 0.0 \\
\hline Environmental Health & 58 & 6 & 10.3 & 8.6 & 0.0 \\
\hline $\begin{array}{c}\text { Garden Club, } \\
\text { Horticultural Program }\end{array}$ & 602 & 5 & 0.8 & 0.5 & 0.0 \\
\hline $\begin{array}{l}\text { Recycling and Reuse } \\
\text { Programs }\end{array}$ & 221 & 5 & 2.3 & 0.5 & 0.0 \\
\hline $\begin{array}{l}\text { Wildlife Sanctuary, } \\
\text { Refuge }\end{array}$ & 98 & 5 & 5.1 & 2.0 & 0.0 \\
\hline $\begin{array}{l}\text { Wastes, Waste } \\
\text { Management }\end{array}$ & 77 & 5 & 6.5 & 3.9 & 0.0 \\
\hline $\begin{array}{l}\text { Pollution Abatement } \\
\text { and Control Services }\end{array}$ & 146 & 4 & 2.7 & 2.1 & 0.0 \\
\hline $\begin{array}{l}\text { Alliance/Advocacy } \\
\text { Organizations }\end{array}$ & 97 & 4 & 4.1 & 2.1 & 0.0 \\
\hline Environmental Media & 44 & 4 & 9.1 & 9.1 & 2.3 \\
\hline $\begin{array}{l}\text { Natural History, Historic } \\
\text { Preservation, Heritage }\end{array}$ & 229 & 3 & 1.3 & 0.9 & 0.0 \\
\hline $\begin{array}{l}\text { Fund Raising and/or } \\
\text { Fund Distribution }\end{array}$ & 144 & 3 & 2.1 & 2.1 & 0.0 \\
\hline Fisheries Resources & 72 & 3 & 4.2 & 2.8 & 0.0 \\
\hline Environmental Law & 42 & 3 & 7.1 & 4.8 & 0.0 \\
\hline Soils & 24 & 2 & 8.3 & 4.2 & 0.0 \\
\hline $\begin{array}{l}\text { Botanical, Horticultural, } \\
\text { and Landscape Services }\end{array}$ & 56 & 1 & 1.8 & 1.8 & 0.0 \\
\hline $\begin{array}{l}\text { Management and } \\
\text { Technical Assistance }\end{array}$ & 98 & 0 & 0.0 & 0.0 & 0.0 \\
\hline
\end{tabular}

\section{References}

1. Taylor, D.E. The Rise of the American Conservation Movement: Power, Privilege, and Environmental Protection; Duke University Press: Durham, NC, USA, 2016.

2. Judd, R.W. Common Lands, Common People: The Origins of Conservation in Northern New England; Harvard University Press: Cambridge, MA, USA, 1997.

3. Reiger, J.F. American Sportsmen and the Origins of Conservation, 3rd ed.; Oregon State University Press: Corvallis, OR, USA, 2001.

4. Cohen, M.P. The History of the Sierra Club: 1892-1970; Sierra Club Books: San Francisco, CA, USA, 1988. 
5. Bramwell, A. Ecology in the 20th Century: A History; Yale University Press: New Haven, CT, USA, 1989.

6. Oelschlaeger, M. The Idea of Wilderness: From Prehistory to the Age of Ecology; Yale University Press: New Haven, CT, USA, 1991.

7. A Hounding Prosecution Threatened. Available online: https://babel.hathitrust.org/cgi/pt?id=mdp. 39015079983071\&view=1up\&seq=559. (accessed on 27 September 2019).

8. Fox, S. The American Conservation Movement: John Muir and His Legacy; University of Wisconsin Press: Madison, WI, USA, 1981; Quotes found on page 359.

9. Trefethen, J.B. An American Crusade for Wildlife; Winchester Press: New York, NY, USA, 1975.

10. Taylor, D.E. Racial and ethnic differences in connectedness to nature and landscape preferences among college students. Environ. Justice 2018, 8, 118-136. [CrossRef]

11. Finney, C. Black Faces, White Spaces: Reimagining the Relationship of African Americans to the Great Outdoors; University of North Carolina Press: Chapel Hill, NC, USA, 2014.

12. Cole, O., Jr. The African-American Experience in the Civilian Conservation Corps; University of Florida Press: Gainesville, FL, USA, 1999.

13. Shabecoff, P. Environmental groups told they are racists in hiring. New York Times, 1 February 1990; A20.

14. Earth Issues Lure a New Breed of Young Worker. Available online: https://www.nytimes.com/1990/07/29/ style/lifestyle-earth-issues-lure-a-new-breed-of-young-worker.html (accessed on 7 July 2019).

15. Environmental Careers Organization. Beyond the Green: Redefining and Diversifying the Environmental Movement; Environmental Careers Organization: Boston, MA, USA, 1992.

16. Taylor, D.E. Blacks and the environment: Toward and explanation of the concern and action gap between Blacks and Whites. Environ. Behav. 1989, 21, 175-205. [CrossRef]

17. Taylor, D.E.; Price, K.; McCoy, E. Diversity Pathways: Broadening Participation in Environmental Organizations; School for the Environment and Natural Resources: Ann Arbor, MI, USA, 2018. [CrossRef]

18. Available online: https://www.ejnet.org/ej/principles.html (accessed on 13 September 2019).

19. Taylor, D.E. Diversity and the environment: Myth-making and the status of minorities in the field. Res. Soc. Probl. Public Policy 2007, 15, 89-148. [CrossRef]

20. Taylor, D.E. Racial and ethnic differences in the students' readiness, identity, perceptions of institutional diversity, and desire to join the environmental workforce. J. Environ. Stud. Sci. 2018, 8, 152-168. [CrossRef]

21. Taylor, D.E. Gender and racial diversity in environmental organizations: Uneven accomplishments and cause for concern. Environ. Justice 2015, 8, 165-180. [CrossRef]

22. Taylor, D.E. The State of Diversity in Environmental Organizations Mainstream NGOs Foundations Government Agencies; University of Michigan, School of Natural Resources and Environment: Ann Arbor, MI, USA, 2014; Available online: https://doi.org/10.13140/RG.2.2.34512.40962 (accessed on 8 July 2019).

23. Deloitte Development LLC. Rewriting the rules for the digital age: 2017 Deloitte Global Human Capital Trends; Deloitte University Press: London, UK, 2017.

24. Forbes Insights. Global Diversity and Inclusion: Fostering Innovation through a Diverse Workforce; Forbes: New York, NY, USA, July 2011.

25. Saxena, A. Workforce diversity: A key to improve productivity. Procedia Econ. Financ. 2014, 11, 76-85. [CrossRef]

26. Shaban, A. Managing and leading a diverse workforce: One of the main challenges in management. Procedia Soc. Behav. Sci. 2016, 230, 76-84. [CrossRef]

27. Cletus, H.E.; Mahmood, N.A.; Abubakar, U.; Ibrahim, A.D. Prospects and challenges of workplace diversity in modern day organizations: A critical review. Holist. J. Bus. Public Adm. 2018, 9, 35-52. [CrossRef]

28. Green, K.A.; López, M.; Wysocki, A.; Kepner, K. Diversity in the Workplace: Benefits, Challenges, and Required Managerial Tools; University of Florida, Institute for Food and Agricultural Services: Gainesville, FL, USA, 2012.

29. Ferrini-Mundy, J. Driven by diversity. Science 2013, 340, 278. [CrossRef]

30. Patrick, H.A.; Kumar, V.R. Managing workplace diversity: Issues and challenges. Sage Open 2012, 2, 1-15. [CrossRef]

31. Frey, W.H. U.S. Will Become "Minority White" in 2045, Census Projects; The Brookings Institute: Washington, DC, USA, 2018.

32. U.S. Census Bureau. Older People Projected to Outnumber Children for the First Time in U.S. History; Department of Commerce: Washington, DC, USA, 2018. 
33. U.S. Census Bureau. Quick Facts. Population Estimates, American Community Survey; Department of Commerce: Washington, DC, USA, 2018.

34. GuideStar. GuideStar Launches First-of-Its-Kind Program to Collect Diversity Data from Nonprofits at Scale. 2014. Available online: https://learn.guidestar.org/news/news-releases/33T2014/guidestar-launches-first-ofits-kind-program-to-collect-diversity-data-from-nonprofits-at-scale (accessed on 20 June 2019).

35. GuideStar, Profile. 2019. Available online: https://www.guidestar.org/profile/94--6069890 (accessed on 9 September 2019).

36. Marrow, J. Green 2.0 reports lack of transparency about diversity by major environmental funders, while many smaller foundations disclosed data. GuideStar Blog. 12 November 2015. Available online: https://trust.guidestar.org/blog/2015/11/12/green-2--0-reports-lack-of-transparency-aboutdiversity-by-major-environmental-funders-while-many-smaller-foundations-disclosed-data/ (accessed on 9 September 2019).

37. Rapson, R. Environmental movement's growth stunted by 'Green Ceiling.' San Francisco Chronicle. 2015. Available online: https://www.diversegreen.org/environmental-movements-growth-stunted-by-greenceiling/ (accessed on 9 September 2019).

38. Harry, J.; Gale, R.; Hendee, J. Conservation: An upper-middle class social movement. J. Leis. Res. 1969, 1, 246-254. [CrossRef]

39. Devall, W.B. Conservation: An upper-middle class social movement: A replication. J. Leis. Res. 1970, 2, 123-126. [CrossRef]

40. Cotgrove, S.; Duff, A. Environmentalism, middle-class radicalism and politics. Sociol. Rev. 1980, $28,333-351$. [CrossRef]

41. Buttel, F.H.; Flinn, W.L. Sources of working class consciousness. Sociol. Focus 1978, 12, 37-52. [CrossRef]

42. Adams, C.E.; Moreno, M. A comparative study of natural resource professionals in minority and majority groups in the Southeastern United States. Wildl. Soc. Bull. 1998, 26, 971-981.

43. Partnership for Public Service. Best Places to Work in the Federal Government, Washington, DC. 2016. Available online: https://public.tableau.com/profile/partnership.for.public.service\#!/ (accessed on 21 August 2019).

44. Partnership for Public Service. Best Places to Work in the Federal Government, Washington, DC. 2007. Available online: https://public.tableau.com/profile/partnership.for.public.service\#!/ (accessed on 21 August 2019).

45. Snow, D. Inside of the Conservation Movement; Island Press: Covelo, CA, USA, 1992.

46. Stanton, R. Environmental Stewardship for the 21st Century: Opportunities and Actions for Improving Cultural Diversity in Conservation Organizations and Programs; Conservation Council of America: Washington, DC, USA, 2002.

47. Stanton, R. Cultural Diversity in Conservation Organizations and Programs: Follow-up Survey of Progress, Initiatives, Programs and Accomplishments by Selected Member Organizations of the Conservation Council of America, May 2002-2004; Conservation Council of America: Washington, DC, USA, 2005.

48. Natural Resources Defense Council (NRDC). NRDC Announces Rhea Suh as New President; Natural Resources Defense Council: New York, NY, USA, 2014; Available online: https://www/nrdc.org/media/2014/140917--0 (accessed on 28 August 2019).

49. Mair, A. A Deeper Shade of Green. Sierra Club: A Power to Change. 2017. Available online: https: //www.sierraclub.org/change/2017/03/deeper-shade-green (accessed on 28 August 2019).

50. Valtin, T. Aaron Mair Elected Sierra Club President. 2015. Available online: https://www.sierraclub.org/ planet/2015/05/aaron-mair-elected-sierra-club-president (accessed on 28 August 2019).

51. Sierra Club. Sierra Club-Meet the Board of Directors. 2018. Available online: https://www.sierraclub.org/ board/meet (accessed on 28 August 2019).

52. Gonzales, N. Environmental Justice Pioneer Deeohn Ferris Joins the National Audubon Society. 2017. Available online: http://www.audubon.org/news/environmental-justicepioneer-deeohn-ferris-joins-nationalaudubon-society (accessed on 29 August 2019).

53. National Wildlife Federation. Mustafa Santiago Ali. Available online: https://www.nwf.org/About-Us/ Leadership/Mustafa-Santiago-Ali (accessed on 10 September 2019). 
54. Green 2.0. Over 25 Top Environmental Advocacy Nonprofits and 8 Top Foundations Submit Diversity Data to GuideStar; Green 2.0 Announces on Earth Day. 2015. Available online: https://www.diversegreen.org/over-25-top-environmental-advocacy-nonprofits-and-8-top-foundationssubmit-diversity-data-to-guidestar-green-2--0-announces-on-earth-day/ (accessed on 29 August 2019).

55. Ahead of Earth Day, Green 2.0 Calls for Leading Organizations to Renew Commitment to Diversity Data Transparency. 2016. Available online: https://www.diversegreen.org/press-release-ahead-earth-day-green-2-0-calls-leading-environmental-organizations-renew-commitment-diversity-data-transparency/ (accessed on 29 August 2019).

56. Taylor, D.E. Diversity in Environmental Organizations: Reporting and Transparency; University of Michigan, School for Environment and Sustainability: Ann Arbor, MI, USA, January 2018.

57. Sundström, A.; Ahmadi, Z.; Mickelsson, K. Implementing social sustainability for innovative industrial work environments. Sustainability 2019, 11, 3402. [CrossRef]

58. Rondinelli, D.A.; Berry, M.A. Environmental citizenship in multinational corporations: Social responsibility and sustainable development. Eur. Manag. J. 2000, 18, 70-84. [CrossRef]

59. Zhuang, Y.; Chang, X.; Lee, Y. Board composition and corporate social responsibility performance: Evidence from Chinese public firms. Sustainability 2018, 10, 2752. [CrossRef]

60. Jenkins, H. Yakovleva, Corporate social responsibility in the mining industry: Exploring trends in social and environmental disclosure. J. Clean. Prod. 2006, 14, 271-284. [CrossRef]

61. Dienes, D.; Velte, P. The impact of supervisory board composition on CSR reporting. Evidence from the German two-tier system. Sustainability 2016, 8, 63. [CrossRef]

62. Liao, L.; Luo, L. Tang, Gender diversity, board independence, environmental committee and greenhouse gas disclosure. Br. Account. Rev. 2015, 47, 409-424. [CrossRef]

63. Rao, K.; Tilt, C. Board diversity and CSR reporting: An Australian study. Meditari Account. Res. 2016, 24, 182-210. [CrossRef]

64. IBM SPSS V25.0 Documentation. Available online: https://www.ibm.com/support/knowledgecenter/en/ SSLVMB_25.0.0/statistics_kc_ddita/spss/product_landing.html (accessed on 9 September 2019).

65. Paul, E. A Better Way to Explore the Nonprofit Sector. 2016. Available online: https://trust.guidestar.org/abetter-way-to-explore-the-nonprofit-sector (accessed on 14 July 2019).

66. Tigas, M.; Wei, S.; Schwencke, K.; Glassford, A. ProPublica: Nonprofit Explorer. Research Tax-Exempt Organizations. 2019. Available online: https://projects.propublica.org/nonprofits/ (accessed on 14 July 2019).

67. Charity Navigator. 2019. Available online: https://www.charitynavigator.org/ (accessed on 14 July 2019).

68. Internal Revenue Service. Annual electronic filing requirements for small exempt organizations-From 990-N (e-Postcard), Washington, DC. 2019. Available online: https://www.irs.gov/charities-non-profits/ annual-electronic-filing-requirement-for-small-exempt-organizations-form-990-n-e-postcard (accessed on 12 July 2019).

69. Internal Revenue Service. Form 990 Series. Which Forms do Exempt Organizations File Filing Phase in? 2019. Available online: https://www.irs.gov/charities-non-profits/form-990-series-which-forms-do-exemptorganizations-file-filing-phase-in (accessed on 12 July 2019).

70. National Center for Charitable Statistics. National Taxonomy of Exempt Entities. 2019. Available online: https://nccs.urban.org/project/national-taxonomy-exempt-entities-ntee-codes (accessed on 14 July 2019).

71. U.S. Census Bureau. The Urban and Rural Classifications. 2013. Available online: https://www2.census.gov/ geo/pdfs/reference/GARM/Ch12GARM.pdf (accessed on 12 September 2019).

72. Ratcliffe, M.; Burd, C.; Holder, K.; Fields, A. Defining Rural at the U.S. American Community Survey and Geography Brief. Department of Commerce: Census Bureau. 2016. Available online: https://www2.census. gov/geo/pdfs/reference/ua/Defining_Rural.pdf (accessed on 12 September 2019).

73. Esri. ArcGIS Online. 2019. Available online: https://www.esri.com/en-us/arcgis/products/arcgis-online/ overview (accessed on 25 July 2019).

74. Esri. ArcMap. 2019. Available online: http://desktop.arcgis.com/en/arcmap/ (accessed on 25 July 2019).

75. DIVA-GIS. 2011. Available online: https://www.diva-gis.org/ (accessed on 25 July 2019). 
76. Esri. WGS 1984 Web Mercator (Auxiliary Sphere) Coordinate System. 2019. Available online: https://pro.arcgis.com/en/pro-app/help/sharing/analyzer-warning-messages/20034-your-web-layerwill-use-the-wgs-1984-web-mercator-coordinate-system.htm (accessed on 25 July 2019).

77. Esri. Geographic Coordinate System. 2019. Available online: https://desktop.arcgis.com/en/arcmap/latest/ map/projections/about-geographic-coordinate-systems.htm (accessed on 26 July 2019).

(C) 2019 by the authors. Licensee MDPI, Basel, Switzerland. This article is an open access article distributed under the terms and conditions of the Creative Commons Attribution (CC BY) license (http://creativecommons.org/licenses/by/4.0/). 